\title{
Expedition 332 summary ${ }^{1}$
}

\author{
Expedition 332 Scientists $^{2}$
}

\section{Chapter contents}

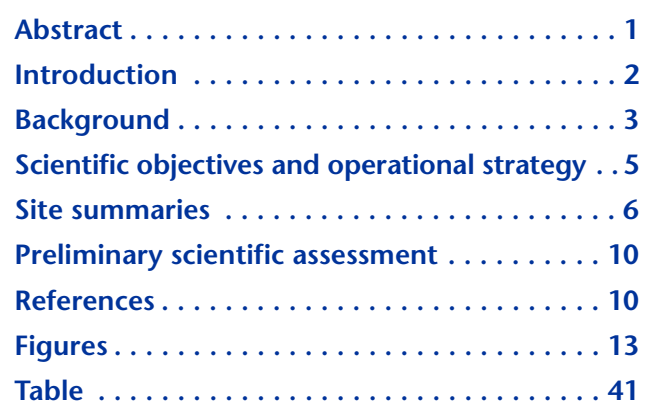

${ }^{1}$ Expedition 332 Scientists, 2011. Expedition 332 summary. In Kopf, A., Araki, E., Toczko, S., and the Expedition 332 Scientists, Proc. IODP, 332: Tokyo (Integrated Ocean Drilling Program Management International, Inc.).

doi:10.2204/iodp.proc.332.101.2011

'Expedition 332 Scientists' addresses.

\section{Abstract}

One primary objective of the Nankai Trough Seismogenic Zone Experiment (NanTroSEIZE) complex drilling project is to drill and instrument a series of holes across the seismogenic subduction system offshore the Kii Peninsula, Japan. Integrated Ocean Drilling Program (IODP) Expedition 332 continued initial observatory operations begun during IODP Expedition 319 in 2009. This expedition focused mainly on engineering work, including (1) retrieval of a temporary observatory instrument ("SmartPlug") installed during Expedition 319 at IODP Site C0010, which penetrates the shallow "megasplay" fault in the mid-forearc; (2) deployment of an upgraded temporary observatory known as a "GeniusPlug" at Site C0010; and (3) installation of a permanent observatory at IODP Site C0002 in the outer Kumano Basin, at the location of planned future deep riser drilling.

Expedition 332 began on 25 October 2010 and ended on 11 December 2010. During the first half of the expedition, the focus was on exchanging the SmartPlug temporary observatory with a GeniusPlug, both attached to a retrievable casing packer above the screened megasplay fault zone at Site C0010. The SmartPlug recovery was successful despite the strong Kuroshio Current, which can be attributed to an efficient reduction of vortexinduced vibration (VIV) on the drill string by attaching ropes. Time series data recovered from the self-contained instrument include seafloor and formation pressure as well as four independent temperature records from the fault zone and the overlying seafloor reference. Tentative analysis of the data documents effective sealing of the bridge plug; dampened pressure amplitudes in the tight, slightly overpressured formation; and identification of prominent earthquake and tsunami events in the 15 month record (23 August 2009-7 November 2010). The SmartPlug was replaced with a GeniusPlug, which is similar in geometry and also self-contained but with the addition of an OsmoSampler for collecting fluids for geochemical analysis and a flow-through osmo colonization system (FLOCS) for microbiological study. The system was installed at a depth that placed the OsmoSampler and FLOCS units in the center of the $22 \mathrm{~m}$ screened cased section across the megasplay fault.

At Site C0002, located $11 \mathrm{~km}$ upslope of Site C0010, a new hole was drilled with logging while drilling (LWD) and cased for placement of a long-term borehole monitoring system (LTBMS). The monitoring system comprises a circulation obviation retrofit kit 
(CORK) assembly with a hydrogeological unit measuring pressure at four depth levels as well as a volumetric strainmeter, broadband seismometer, tiltmeter, geophones, accelerometers, and a thermistor string. The key goals include pore pressure monitoring in the upper accretionary prism (Unit IV), a series of measurements in the homogeneous sediments of Unit III (strain, tilt, seismicity, and pressure) in the sediments at the base of the Kumano Basin fill, directly overlying the accretionary prism below, and temperature and pressure monitoring in the overlying Kumano Basin sediments of Unit II. The string of the LTBMS assembly had a total length of $965 \mathrm{~m}$ and was carefully secured during deployment with centralizers, bands, and straps to withstand the strong current. VIV was minimized using ropes, and acceleration was monitored during deployment. The lower portion of the assembly is hydraulically isolated from the overlying ocean by a swellable packer placed at 746 meters below seafloor (mbsf). Part of the instrument string below was cemented ( 780-935 mbsf) to couple the strainmeter and seismometer to the formation/casing. The CORK head was revisited prior to and after cementing for system tests of the borehole instruments using the remotely operated vehicle (ROV), and all of these experiments were successful. The CORK was left with minimum battery power after the expedition and will be revisited in 2011 by ROV to connect an additional seafloor unit for power and data storage. In winter 2011/2012, the unit is anticipated to be connected to the real-time seafloor cabled network Dense Oceanfloor Network System for Earthquakes and Tsunamis (DONET).

\section{Introduction}

\section{Overview of the NanTroSEIZE complex drilling project}

Subduction zones account for the majority of global seismic moment release, and slip along subduction megathrusts generates both damaging earthquakes and tsunamis (e.g., Lay et al., 2005). Understanding the processes that govern the distribution, mechanics, and style of slip along subduction and other plate boundary fault systems is essential to earthquake and tsunami hazard assessment. To this end, several recent and ongoing drilling programs have targeted portions of active plate boundary faults that have either slipped coseismically during large earthquakes or nucleated smaller events. These efforts include the San Andreas Fault Observatory at Depth (SAFOD) (Hickman et al., 2004), the Taiwan-Chelungpu Drilling Project (Ma, 2005), and Integrated Ocean Drilling Program (IODP) Nankai Trough Seismogenic Zone Experiment (NanTroSEIZE) drilling (Tobin and Kinoshita, 2006a, 2006b).
NanTroSEIZE is a multiexpedition, multistage IODP drilling project focused on understanding the mechanics of subduction plate boundary faults. The drilling program includes a coordinated effort to characterize, sample, and instrument the plate boundary system at several locations offshore the Kii Peninsula (Fig. F1), culminating in drilling, sampling, and instrumenting the plate boundary fault system near the updip limit of inferred coseismic slip, at $5 \sim 7 \mathrm{~km}$ below seafloor (Tobin and Kinoshita, 2006b) (Fig. F2) and installation of a distributed network of integrated borehole observatories to monitor strain and seismological, thermal, and hydrological processes. The main scientific objectives of drilling and monitoring are to understand and test

- Hypothesized mechanisms controlling the transition from predominantly aseismic creep at shallow depths and near the trench to seismic slip and interseismic locking at greater depths along the megathrust fault system;

- Frictional and hydrologic processes governing the mode of fault slip, strain accumulation, and release;

- The absolute mechanical strength of the plate boundary fault; and

- The potential role of a major upper plate fault system (termed the "megasplay" fault) in seismogenesis and tsunamigenesis.

In the NanTroSEIZE study area, high-resolution seismic reflection profiles across the outer rise clearly document a major out-of-sequence thrust fault system (megasplay fault, after Park et al., 2002) that branches from the décollement close to the updip limit of inferred coseismic rupture in the 1944 Tonankai M 8.2 earthquake (Fig. F2). Several lines of evidence indicate that the megasplay system is active, may accommodate a significant fraction of plate boundary motion, and may slip coseismically; these are discussed in more detail in "Geological setting" below (Moore et al., 2007; Strasser et al., 2009). However, the partitioning of strain between the lower plate interface (the décollement zone) and the megasplay system and the nature and mechanisms of fault slip as a function of depth and time on the megasplay are not understood. Thus, the megasplay and the region near its updip terminus comprise one of the primary drilling and monitoring targets for NanTroSEIZE.

In late 2007 through early 2008, NanTroSEIZE Stage 1 was conducted as a unified program of drilling, comprising IODP Expeditions 314, 315, and 316 (Kinoshita, Tobin, Ashi, Kimura, Lallemant, Screaton, Curewitz, Masago, Moe, and the Expedition 314/315/316 Scientists, 2009). Drilling during Stage 
1 included riserless drilling along a transect of eight sites that targeted the frontal thrust region near the trench, the megasplay fault region, and the Kumano forearc basin region (Fig. F2). One of these sites, IODP Site C0002, also served as a preparatory pilot hole for planned future deep riser drilling. The other drill sites primarily targeted fault zones and accretionary prism sediments in the shallow, presumed aseismic portions of the accretionary complex (Kinoshita, Tobin, Ashi, Kimura, Lallemant, Screaton, Curewitz, Masago, Moe, and the Expedition 314/315/316 Scientists, 2009). Expedition 314 was dedicated to in situ measurement of physical properties and borehole imaging through a comprehensive logging-while-drilling (LWD) program (Kinoshita et al., 2008). Expedition 315 focused on coring and downhole temperature measurements at one site in the megasplay region (IODP Site C0001) and one in the forearc basin (Site C0002) (Ashi et al., 2008). Expedition 316 cored and conducted downhole temperature measurements across the frontal thrust and megasplay fault near their updip termini (Kimura et al., 2008).

NanTroSEIZE Stage 2 included two expeditions in 2009 (IODP Expeditions 319 and 322), with the aims of building on the results of Stage 1 and preparing for observatory installations. Expedition 319 investigated the properties, structure, and state of stress within the hanging wall above the locked plate boundary at IODP Site C0009 and across the shallow megasplay fault at IODP Site C0010. In addition, the first temporary long-term borehole observatory, a SmartPlug, was successfully installed at Site C0010 in an interval of screened casing across the megasplay fault (Saffer, McNeill, Byrne, Araki, Toczko, Eguchi, Takahashi, and the Expedition 319 Scientists, 2010). Expedition 322 sampled and characterized the properties of sediments entering the subduction zone on the subducting Philippine Sea plate (Saito, Underwood, Kubo, and the Expedition 322 Scientists, 2010).

IODP Expedition 332 continued NanTroSEIZE Stage 2 operations, using data generated during previous expeditions in Stages 1 and 2 as well as infrastructure provided by the cased Hole C0010A to continue riserless observatory operations along the NanTroSEIZE transect.

\section{Background Geological setting}

The Nankai Trough is formed by subduction of the Philippine Sea plate underneath southwestern Japan at a rate of $\sim 4.1-6.5 \mathrm{~cm} / \mathrm{y}$ along an azimuth of $300^{\circ}-$ $315^{\circ} \mathrm{N}$ (Seno et al., 1993; Miyazaki and Heki, 2001).
In the outer forearc, the plate interface dips $3^{\circ}-7^{\circ}$ (Kodaira et al., 2000). The Nankai Trough subduction zone forms an end-member sediment-dominated accretionary prism similar to the Mediterranean Ridge (Kopf et al., 2003). In the toe region, a sedimentary section $\sim 1-1.5 \mathrm{~km}$ thick is accreted to or underthrust below the margin (Moore, Taira, Klaus, et al., 2001; Moore et al., 2009).

The three major seismic stratigraphic sequences identified in the northern Shikoku Basin are the lower and upper Shikoku Basin sequences and the Quaternary turbidite sequence. The upper Shikoku Basin facies off Kumano decreases slightly in thickness toward the north, whereas the lower Shikoku Basin facies displays a much more complicated geometry as a result of the effects of basement topography (Le Pichon et al., 1987a, 1987b; Mazzotti et al., 2000; Moore, Taira, Klaus, et al., 2001; Ike et al., 2008a, 2008b). Its thickness decreases above basement highs, and a more transparent acoustic character indicates local absence of sand packages that characterize most other parts of the lower Shikoku Basin. The mechanical differences between subducting basement highs and subducting basement plains could be significant for fault zone dynamics and earthquake rupture behavior (Bilek et al., 2003).

The deformation front behavior off Kumano is fundamentally different than it is at previous targets of Ocean Drilling Program (ODP) drilling offshore of Capes Muroto and Ashizuri, $\sim 200-300 \mathrm{~km}$ to the southwest (Taira, Hill, Firth, et al., 1991; Moore, Taira, Klaus, et al., 2001). Seismic reflection data off Kumano clearly delineate the frontal fault near the prism toe; however, there is little evidence for seaward propagation of the décollement within the deeper Shikoku Basin strata (see Proposal 603A-Full2 at www.iodp.org/600/). One interpretation of the seismic profile is that the décollement steps up to the seafloor, thereby thrusting older accretionary prism strata over the upper Quaternary trench-wedge facies (Fig. F2). Manned submersible observations also indicate that semilithified strata of unknown age have been uplifted and exposed along a fault scarp at the prism toe (Ashi et al., 2002). Farther inboard, the fault ramps down into the lower Shikoku Basin facies (Park et al., 2002).

The lower forearc slope consists of a series of thrust faults that have shortened the accreted sedimentary units of the accretionary prism. A combination of swath bathymetric and multichannel seismic data show a pronounced continuous outer ridge (outer arc high) of topography extending $>120 \mathrm{~km}$ along strike, which may be related to megasplay fault slip (e.g., Moore et al., 2007; Strasser et al., 2009). Remotely operated vehicle (ROV) and manned submersible 
diving surveys along this feature reveal a very steep slope on both sides of the ridge (Ashi et al., 2002; J. Ashi et al., unpubl. data). The outer arc high coincides with the seaward edge of a system of thrust faults that branch from the megasplay.

The megasplay is a major structural boundary within the accretionary wedge, traverses the entire wedge, and has had a protracted history of activity as shown by the thick forearc basin trapped behind its leading edge (Moore et al., 2007). The megasplay is also hypothesized to represent a discontinuity in rock physical properties and fault mechanical boundary between the inner and outer accretionary wedge and perhaps between aseismic and seismogenic fault behavior (Wang and $\mathrm{Hu}, 2006$ ). At depth, the megasplay is imaged in seismic reflection data as a highamplitude reflector (Bangs et al., 2009) (Fig. F2), and it branches into a family of smaller splays in the upper few kilometers below the seafloor, including the fault penetrated at IODP Sites C0004 and C0010. The most direct evidence for recent megasplay fault activity comes from stratigraphic relationships at the tips of the faults in young slope sediments. Direct fault intersections with the seafloor are not observed (Moore et al., 2007; Strasser et al., 2009); however, the thrust sheets wedge into these deposits, causing tilt and slumping of even the deposits nearest to the surface. Evidence for mass wasting complexes is consequently found at IODP Sites C0004, C0008, and C0010. The latter, as well as Site C0002 further landward, were the target areas of Expedition 332.

Site C0010, located $3.5 \mathrm{~km}$ southeast of previously completed Site C0004, was first drilled during Expedition 319 (Saffer, McNeill, Byrne, Araki, Toczko, Eguchi, Takahashi, and the Expedition 319 Scientists, 2010). Operations during that expedition included drilling through the megasplay fault zone and into its footwall using LWD, setting casing with screens across the fault zone, and installing a simple and temporary borehole observatory (a SmartPlug) to monitor fluid pressure and temperature in the shallow megasplay. Major lithologic boundaries as well as the location of the megasplay fault at 407 meters below seafloor (mbsf) were identified in LWD data and were used to select a depth interval spanning the fault for placement of the two screened casing joints. Three distinct lithologic packages were observed at Site C0010: slope deposits (Unit I, 0182.5 mbsf), thrust wedge (Unit II, 182.5-407 mbsf), and overridden slope deposits (Unit III, 407 mbsf to total depth [TD]) (Fig. F3). Unit I is similar to Unit I described previously at Site C0004 and was interpreted as hemipelagic slope sediments composed primarily of mud with minor distal turbidite interbeds.
The thrust wedge (Unit II) is clayey and characterized by high and variable gamma ray and resistivity values compared with the units above and below. Unit III is composed of hemipelagic muds with minor turbidite interbeds and rare volcanic ash layers.

Site C0002 is located near the southeastern edge of the Kumano Basin (Fig. F2). The Kumano Basin has a generally flat bathymetry, with a water depth of $\sim 2000 \mathrm{~m}$. The sediments in the southern part of the Kumano Basin are tilted northward, truncated by a flat erosional surface, and subsequently cut by normal faults (Park et al., 2002; Ashi et al., 2008; Moore et al., 2009). Lithostratigraphy at Site C0002 (Fig. F3) is characterized by turbiditic sediments to $\sim 830 \mathrm{mbsf}$, underlain by older rocks of the accretionary prism and/or early slope basin sediments deposited prior to the development of the megasplay fault, which were drilled and partly cored during Expeditions 314 and 315. Expedition 332 revisited Site C0002, drilling with a limited suite of $\mathrm{LWD} /$ measurement-while-drilling (MWD) tools, for reconnaissance and to identify the most suitable depth intervals to place sensors of the long-term borehole monitoring system (LTBMS) (see "Site C0002 riserless observatory").

\section{Seismic studies/Site survey data}

The Kii and Kumano Basin region is among the beststudied subduction zone forearcs in the world. A significant volume of site survey data has been collected in the drilling area over many years, including multiple generations of 2-D seismic reflection (e.g., Park et al., 2002), wide-angle refraction (Nakanishi et al., 2002, 2008), passive seismicity (e.g., Obana et al., 2001), heat flow (Yamano et al., 2003), side-scan sonar, and swath bathymetry as well as submersible and ROV dive studies (Ashi et al., 2002). In 2006, a joint, 3-D seismic reflection survey was conducted by Japanese and US scientists over a $\sim 11 \mathrm{~km} \times 55 \mathrm{~km}$ area, acquired under contract by Petroleum GeoServices, an industry service company (Fig. F1) (Moore et al., 2007). The poststack trace spacing is $12.5 \mathrm{~m}$ in the in-line direction and $18.75 \mathrm{~m}$ in the cross-line direction. This 3-D volume-the first deep-penetration, fully 3-D marine survey ever acquired for basic research purposes-has been used to refine the selection of drill sites and targets in the complex megasplay fault region and define the regional structure and seismic stratigraphy (Moore et al., 2009). As NanTroSEIZE drilling proceeds, the 3-D seismic data will continue to be used to refine drilling and operational strategies, to analyze physical properties of the subsurface through seismic attribute studies, to extend findings in the boreholes to wider areas, and to assess drilling safety. 


\section{Scientific objectives and operational strategy}

Long-term monitoring within a network of boreholes along the Kii drilling transect is one of the central objectives of NanTroSEIZE and is critical in order to shed light on potential changes in mechanical and hydrologic properties through the seismic cycle, define the upper transition from aseismic to seismic deformation and distribution of interseismic strain accumulation, and assess the role of the megasplay in accommodating slip. Therefore, Expedition 332 followed up on the riserless observatory installations begun during Expedition 319 in summer 2009. Our activities focused on two sites:

- Site C0010, drilled and cased across the shallow megasplay fault and into its footwall, has been identified as a high-priority target for permanent long-term monitoring. However, because no LTBMS was available for Expedition 319, a simple temporary pore pressure and temperature observatory (SmartPlug) was installed in 2009 (Saffer, McNeill, Byrne, Araki, Toczko, Eguchi, Takahashi, and the Expedition 319 Scientists, 2010). The objectives for Expedition 332 included recovering the SmartPlug and replacing it with the upgraded temporary observatory that also includes geochemical sampling capability and in situ microbiological culturing media, termed a "GeniusPlug."

- Site C0002 is also identified as a high-priority target for permanent long-term monitoring. Ultimately, observatory instruments at this location will be installed in two boreholes: one $\sim 1 \mathrm{~km}$ deep riserless LTBMS and one deep riser completion at $\sim 5-7 \mathrm{~km}$ below seafloor. The main goal of Expedition 332 was to drill and case a borehole at Site C0002 and install an integrated LTBMS that combines thermal, hydrologic, and geodynamic sensors to monitor pore fluid pressure, temperature, strain, tilt, and seismicity. The installation contains four major components: bottom-hole instruments and hydraulic screens, tubing to provide mechanical support for downhole cables and hydraulic lines, a swellable packer to provide hydraulic isolation between the formation below and the overlying ocean, and a wellhead similar to those used for previous circulation obviation retrofit kit (CORK) installations during ODP and IODP (Becker and Davis, 2005). The wellhead is designed to land at the casing hanger and suspend the tubing, packer, and instruments below. The instruments include a broadband seismometer, a tiltmeter combo, a thermistor string, and a strainmeter (see "Site C0002 riserless observatory").

The operations summary for Expedition 332 is shown in Table T1. After departure from Shingu, Japan, port on 27 October 2010, the D/V Chikyu evacuated from Typhoon Chaba, carried out additional loading of equipment at sea, and started drilling operations at Site C0010 on 2 November. At Site C0010, operations began with an ROV dive to place transponders on the seafloor and recalibrate the dynamic positioning system. The Chikyu then moved to a low-current area on 3 November to start lowering the casing packer retrieving assembly and running tool. While lowering the string through and in the Kuroshio Current, two accelerometer packages to monitor vortex-induced vibration (VIV) were attached to the drill string at two depth levels. In parallel, ropes were attached the upper $500 \mathrm{~m}$ of the drill string, where current velocities are highest. Once the bottom-hole assembly (BHA) neared the seafloor, the ROV was launched to assist reentry into Hole C0010A, which took place around noon on 5 November. The assembly latched onto the retrievable bridge plug $5 \mathrm{~h}$ later, and the bridge plug and SmartPlug were pulled out of the hole in the early morning of 6 November. At 1400 h on 7 November, the bridge plug and SmartPlug were recovered on the rig floor. We detached the SmartPlug and downloaded and processed the stored data. Hole C0010A was covered with the corrosion cap and transponders were recovered before moving to Site C0002.

At Site $\mathrm{C0002}$, transponders were already in place from drilling during IODP Expedition 326 (NanTroSEIZE Stage 3: plate boundary deep riser: top hole engineering) in summer 2010 (Expedition 326 Scientists, 2011). The Chikyu moved upstream of Site C0002 on 13 November and prepared to run the drilling BHA into the water. Anti-VIV ropes were attached to the string and the vessel started to drift toward the site. Jetting in began on 15 November. After completing additional loading via supply boat, reaming of the hole and drilling using the LWD/ MWD BHA commenced on 17 November. First, a $12^{1 / 4}$ inch hole was drilled to 892 mbsf and logging data were collected with a limited suite of LWD/ MWD tools (MWD PowerPulse/TeleScope, annular pressure while drilling [APWD], and arcVISION array resistivity compensated tool with natural gamma radiation detection and attenuation resistivity). After pulling the drill string, a $105 \%$ inch BHA was run in to deepen the hole to a TD of 980 mbsf. This was mostly done to maintain a small hole diameter and minimize disturbance in the anticipated target depth for the cemented instruments. LWD data were collected during drilling of the 105/8 inch hole from 892 to 980 mbsf, with a section of the hole relogged because of failure in the live streaming of LWD data. After a wiper trip and some reaming, the hole was found to be in good condition and casing (including screened casing joints set for 757-780 mbsf) was 
lowered on 22 November. During casing operations, the accelerometer packages as well as anti-VIV ropes were run again. Casing operations were completed early on 25 November, and the BHA was pulled out of the hole in order to have a short port call at Shimizu, Japan, on 27 November.

Once back at the site of Hole C0002G, drilling out the cement started on 29 November before the hole was swept and spotted with high-density brine and a high-viscosity temporary gel for later reentry and LTBMS hole completion. Early on 30 November the CORK running tool was picked up, running in the hole began, and the flatpack umbilical, three cables for CORK instruments, and the thermistor string were terminated and connected. From 1 December, joints of $3 \frac{1}{2}$ inch tubing were slowly run down with four centralizers per joint, with additional tie wraps and metal bands attached every $\sim 1 \mathrm{~m}$ to secure the cables, thermistor, and flatpack. From 2 December onward, the number of centralizers per joint was reduced from four to two, with a corresponding increase in speed and efficiency. The swellable packer was slit and the cables were fed through its body seal a day later before lowering tubing commenced. Both prior and after packer operations, the CORK instruments were tested via an interface and extension leads to a container unit in the moonpool area. From late on 2 December into the morning of 3 December, the CORK head was picked up on the rig floor, latched to the CORK running tool, and lowered into the moonpool area. The electrical cables and flatpack umbilical were measured, cut, and terminated thereafter and tested prior to and after mounting them to the CORK head assembly. All tests were successful so the ROV platform could be attached, and the CORK head assembly finally entered the water in the evening of 5 December. Three more CORK component tests were carried out: before drifting to the site (CORK head at 350 meters below sea level), after drifting (above the hole), and after landing of the CORK head in the well. The last of these tests was successfully completed late on 8 December. Cementing through a cement port at $937 \mathrm{mbsf}$ took place on the morning of 9 December, and a final check of the hydrogeologic unit at the CORK head took place by ROV $15 \mathrm{~h}$ later before the transponders were recovered. Expedition 332 ended at sea on 11 December, and scientists were exchanged via helicopter.

\section{Site summaries}

\section{Site $\mathrm{C} 0010$ riserless observatory}

Hole C0010A $=33^{\circ} 12.5981^{\prime} \mathrm{N}, 136^{\circ} 41.1924^{\prime} \mathrm{E}$

Water depth $=2523.7 \mathrm{~m}$

Drilling depth $=555$ mbsf (Table T1)
Site C0010 is one of the key observatory sites because it intersects a branch of the megasplay fault at 410 mbsf (see Saffer, McNeill, Byrne, Araki, Toczko, Eguchi, Takahashi, and the Expedition 319 Scientists, 2010) (Figs. F3, F4). During Expedition 332, the site was revisited about 15 months after the hole was drilled and cased. The two major objectives this time were (1) to recover the SmartPlug temporary observatory installed in 2009 and (2) to replace it with a GeniusPlug temporary observatory. No drilling, LWD/MWD, or other operations were performed at this site, which is the planned location for a LTBMS.

A number of science objectives for Site C0010 were achieved during Expedition 319 in 2009, including drilling with LWD/MWD across the megasplay fault to TD of $560 \mathrm{mbsf}$, casing the borehole (with casing screens at the fault), and installation of a simple pore pressure and temperature monitoring system (SmartPlug). It was possible to (1) define major lithologic unit boundaries of the shallow megasplay fault zone and (2) determine the preferred placement of screened casing joints spanning the megasplay fault zone for observatory monitoring (Fig. F3). Through comparison with previously drilled Site C0004 located $\sim 3.5 \mathrm{~km}$ along strike (Kinoshita, Tobin, Ashi, Kimura, Lallemant, Screaton, Curewitz, Masago, Moe, and the Expedition 314/315/316 Scientists, 2009) these data also provide insights into alongstrike differences in the architecture of the megasplay fault and hanging wall (Flemings et al., 2009).

Although the SmartPlug is a relatively simple instrument, it marks the first observatory placement during the NanTroSEIZE project. The instrument contains a cylindrical steel hull with an internal metal frame that hosts the electronics and transducers (see Fig. F5). The inner section is cushioned against shock and is therefore suitable for installation in the Kuroshio Current and other high-current areas where VIV during deployment may be a concern. The instrument package includes a data logger, a temperature sensor within the data logger housing, a self-contained temperature sensor, and two pressure gauges (one "upward looking" and one "downward looking"). These sensors monitor pressure (1) below the packer seal in a screened interval that is open to the fault zone and (2) above the packer seal to serve as a hydrostatic reference open to the overlying water column. In addition to the thermistors incorporated with the pressure transducers for thermal compensation, two independent temperature sensors are included in the SmartPlug. These two temperature sensors are at a depth just below the packer in the upward-looking section of the casing packer. The retrieval of the SmartPlug allows the collection of the first observatory data (pressure and temperature) from the shallow section of the megasplay fault, as 
well as an evaluation of observatory installation procedures in the Kuroshio Current. These data will be invaluable in planning for future permanent observatory installation.

After reentry into Hole C0010A, the latching tool connected to the retrievable bridge plug without much effort, and the bridge plug and SmartPlug package was safely pulled out of the hole only a few hours after reentry (Fig. F6). On a long but careful recovery trip through the water column, the SmartPlug remained undamaged and was recovered safely on deck on 7 November (Fig. F6). Once the tack-welding points of the SmartPlug-to-bridge plug connection were cut, the SmartPlug was unscrewed; corrosion was found on the outside and inside of the instrument, most likely a result of the rusted inner casing of the borehole.

The SmartPlug sensor carrier with the pressure transducers, miniature temperature logger (MTL), and pressure housing containing the data logger was cleaned prior to hooking it to a computer via the AQW connector for data download. A full record of the deployment period (23 August 2009-7 November 2010) plus $\sim 2$ weeks prior to the deployment was recovered from all transducers and the MTL, attesting to the robust design of the instrument. Full-time series records are shown for the upward-looking (hydrostatic reference) and downward-looking (megasplay fault zone) pressure (Fig. F7) and the platinum chip and MTL temperature (Fig. F8). The full records clearly show an increase in pressure and decrease in temperature as the instrument entered the water and was lowered toward and into the seafloor. Thereafter, equilibration began, but both records suggest that the borehole had not fully equilibrated by the time we recovered the instrument (see Figs. F7, F8). The data also show that the bridge plug effectively sealed the borehole because upon reentry of the drill string and latching onto the device during Expedition 332, the upward-looking pressure sensor shows a strong fluctuation owing to displacement of borehole fluid, whereas the downward-looking pressure sensor recorded a near-constant signal (Fig. F9).

In order to illustrate some of these findings, we provide a few preliminary data examples of pressure and temperature. Figure F10 provides an example of the tidal forcing seen in the upward- and downwardlooking pressure transducers. As is consistent with the expectation from a subseafloor formation, the response of formation pore pressure to ocean tidal loading is characterized by diminished amplitude and a small phase shift relative to the seafloor tide (Wang and Davis, 1996).

A cursory review of the data identified multiple pressure and-to a lesser extent-temperature excursions that may be related to seismic events, although further detrending and processing of the data are required to filter the tidal signal and resolve pressure anomalies. Nevertheless, several earthquakes that took place during the deployment period generated pressure signals that were resolvable by the SmartPlug despite the sampling interval of $60 \mathrm{~s}$ for this deployment. Figure F11 shows the sinoidal records of the seafloor and formation pressure data, showing the signal from the M 8.8 Maule (Chile) earthquake event in the early part of the record. About $24 \mathrm{~h}$ after initial arrival of the pressure waves, the associated tsunami had crossed the Pacific Ocean and loaded the formation at Site C0010. Many similar examples are found in the time series record (Kopf et al., 2011). In contrast to the pressure responses recorded, temperature signals are less pronounced and, thus, more ambiguous. There are numerous examples where temperature remains unchanged while pressure shows excursions related to seismic or wave loading. On the other hand, significant changes in temperature were recorded on one occasion on 29 May 2010 (Fig. F12). Interestingly, no significant change in pressure was recorded around that time. Also, it remains unresolved why three thermistors show an increase in temperature while the platinum chip temperature drops slightly. At this point, neither a seismic event nor any other natural explanation for the observed shifts in temperature can be provided. Presumably, artifacts such as settling of the instrument or fluid circulation may help explain the temperature changes but would have ultimately caused the pressure to vary as well (which is not the case).

The SmartPlug record contains a number of events seen in both the pressure and temperature data, which will be studied in more detail after Expedition 332. At first glance, however, the following summary statements can be made:

1. The plug apparently settled about $50 \mathrm{~cm}$ over the first 2 months, or some of the thread grease or anticorrosion additive to the borehole fluid was mucking the inside of the instrument (and hence the upward-looking pressure transducer) and loaded the seafloor sensor.

2. The formation appears to be overpressured by $\sim 10 \mathrm{kPa}$ and was still recovering at the end of the record.

3. The pressure records captured pressure and tsunami waves associated with several earthquake events. The tsunami waveform related to the M 8.8 Maule, Chile, earthquake is similar to existing records from, for example, the NEPTUNE seafloor cabled network (E. Davis, pers. comm., 2010) but has larger amplitude and a more persistent pressure signal lasting 3-4 days (see Fig. F11, and Kopf et al., 2011). 
4. The temperature records are well resolved but show yet-to-be-explained offsets, which may either have something to do with a change in the thermal insulation around the sensors or the instrument pressure case, the changing nature of heat dissipation, or hydrogeologic events such as earthquake loading of the formation. Postcruise research may shed light on the observed problem of opposite temperature trends from the different sensors during the same event (Fig. F12).

5. The loading efficiency of $\sim 0.8$ at tsunami frequency is very similar to that at tidal frequency. Rayleigh and pressure waves are much larger in the formation relative to the water column, whereas for the oceanographic loading from tides and the Chile earthquake tsunami, the formation signal is damped compared to that measured at the seafloor reference port (Fig. F10).

More information regarding both the instrument and the data set and the interpretation of the results can be found in Kopf et al. (2011).

One additional data record collected during the SmartPlug deployment at Site C0010 is triaxial accelerometer data monitoring drill string VIV. This measurement was taken after the problems associated with some of the observatory installation procedures tested during Expedition 319 (for details see Saffer, McNeill, Byrne, Araki, Toczko, Eguchi, Takahashi, and the Expedition 319 Scientists, 2010). In 2009, an instrument carrier was damaged and two borehole instruments were lost while another's internal circuitry was destroyed by drill string VIV-induced shocks. As a result, from fall 2009 to spring 2010 the Japan Agency for Marine-Earth Science and Technology (JAMSTEC) tested various techniques on land to minimize/reduce VIV and demonstrated that VIV related to strong currents can be efficiently reduced by attaching ropes along the axis of the drill string. This was successfully tested in the field during a Chikyu shakedown cruise in March 2010, and this technique was made a routine part of observatory operations in the high-velocity regions of the Kuroshio Current.

During Expedition 332, a set of four ropes was attached in the moonpool area when the drill string was passing from the rig floor into the water (Fig. F13). The attachment was carried out in the upper $500 \mathrm{~m}$ of the drill string where the current velocities are the highest. Figure F14 demonstrates how the ropes serve to reduce VIV along the drill string where the sensitive observatory instruments are located. VIV in the upper part of the drill string increased slightly when compared to a deployment free of ropes; however, such vibrations are tolerable given that no electronics or other sensitive parts are housed there. During drifting for SmartPlug retrieval at Site C0010 (see Fig. F14), we encountered accelerations of $\sim 0.5 \mathrm{~g}$ or less. This value was even lower at slower drift speeds (e.g., at Site C0002), where acceleration did not exceed $0.2 \mathrm{~g}$. The angle between drifting direction and sea current was $\sim 45^{\circ}$, which also helped to reduce VIV. This finding has important repercussions for future observatory installations.

Once the SmartPlug and accelerometer instruments were safely recovered, the final step of the temporary instrumentation operations was the first deployment of a GeniusPlug (Fig. F15) in IODP history. The GeniusPlug is similar to the SmartPlug, except that the instrument is $\sim 30 \mathrm{~cm}$ longer, and it includes an OsmoSampler for fluid sampling over time as well as the osmotically driven microbiology chambers of the flow-through osmo colonization system (FLOCS) unit. For fluid sampling, it is especially important that final instrument placement is close to the screened interval; therefore, the bridge plug assembly was adjusted to include two joints of $3 \frac{1}{2}$ inch tubing, which were added between the instrument and the bridge plug (Fig. F4). The GeniusPlug was set up to sample fluids for up to 24 months and was deployed after a short drifting period with ropes but no accelerometer instruments attached to the drill string. The wellhead was protected using a corrosion cap and will be revisited for instrument recovery.

\section{Site $\mathrm{C0002}$ riserless observatory}

Hole $\mathrm{C} 0002 \mathrm{G}=33^{\circ} 18.0126^{\prime} \mathrm{N}, 136^{\circ} 38.1488^{\prime} \mathrm{E}$

Water depth $=1937.5 \mathrm{~m}$

Drilling depth $=980$ mbsf (Table T1)

Site C0002 is the centerpiece of the NanTroSEIZE project, intended to access the plate interface fault system at a location where it is believed to be capable of seismogenic locking and in a zone thought to have slipped coseismically in the 1944 Tonankai earthquake. The primary targets include both the basal décollement at $\sim 6200$ mbsf and the megasplay fault (Tobin and Kinoshita, 2006b). The megasplay fault reflector lies at an estimated depth of 5000 5200 mbsf, and the top of the subducting basement is estimated to lie at 6800 7000 mbsf (Figs. F1, F2).

At Site C0002, several scientific objectives were achieved during previous expeditions, during which a total of six holes have been drilled within a $100 \mathrm{~m}$ radius (Kinoshita, Tobin, Ashi, Kimura, Lallemant, Screaton, Curewitz, Masago, Moe, and the Expedition 314/315/316 Scientists, 2009). Operations included drilling and logging with a full suite of LWD/MWD to 1400 mbsf during Expedition 314 and coring two intervals from 0 to 204 mbsf and 475 to $1057 \mathrm{mbsf}$ during Expedition 315 (Fig. F3). The succession 
explored comprises four units, the upper three of which are different lithofacies in the Kumano forearc basin. From $~ 920$ to 936 mbsf, the transition zone to the underlying accreted strata was found. The primary objective at Site C0002 during Expedition 332 was to install the first permanent borehole observatory system during the NanTroSEIZE project into the basal forearc basin (Unit III, dominated by condensed mudstone) and the upper accretionary prism (Unit IV, containing interbeds of mudstone, siltstone, and sandstone) (Fig. F3, F16).

The suite of sensors for the downhole portion of the observatory includes (1) pressure ports, (2) a volumetric strainmeter, (3) a broadband seismometer, (4) a tiltmeter, (5) three-component geophones, (6) three-component accelerometers, and (7) a thermometer array (Fig. F16). For practical reasons, downhole components 4-7 are incorporated into one system, so the observatory includes

- The hydrogeological component with a pressure unit at the CORK head and a flatpack umbilical with three stainless steel hydraulic lines running into the hole and terminated at a different depths,

- The strainmeter,

- The broadband seismometer, and

- The tilt combo instrument with a thermistor string.

The set of sensors is designed to collect, as a whole, multiparameter observations at periods ranging from months to $1 / 100 \mathrm{~S}$ and a wide dynamic range covering events from local microearthquakes, very low frequency earthquakes, to the largest earthquake slips of the Tonankai plate boundary $6 \mathrm{~km}$ below the sensors. The hydrogeologic component of the sensor set is further laid out to monitor formation pressures at three downhole levels and further records data from a seafloor pressure port for reference.

In preparation for LTBMS installation, Hole C0002G was drilled without coring but with three LWD runs (once with a 121/4 inch assembly and twice with a $105 / 8$ inch assembly), with a maximum rate of penetration of $20-30 \mathrm{~m} / \mathrm{h}$, in order to achieve a high data resolution in order to identify the most promising locations for LTBMS instrument locations. Both resistivity and natural gamma ray were measured to confirm the anticipated depths of lithologic boundaries identified during previous drilling of nearby Hole C0002A (Expedition 314; see Kinoshita, Tobin, Ashi, Kimura, Lallemant, Screaton, Curewitz, Masago, Moe, and the Expedition 314/315/316 Scientists, 2009). Changes in composition and texture were identified by variations in natural gamma values that coincided with changes in electrical resistivity. LWD data confirm that both the depth and character of the target formation (Unit III) were broadly consistent with previous logging (Fig. F3). In particular, a marked decrease in the resistivity fluctuations coupled with an increase in natural gamma values defined the Unit II/III boundary. The lower boundary of Unit III was also identified clearly from the gamma and resistivity logs. The strainmeter was positioned fully within the relatively homogeneous and continuous zone of elevated gamma ray and resistivity values, interpreted as homogeneous mudstone (Ashi et al., 2008).

A 20 inch conductor pipe was jetted in to $41 \mathrm{mbsf}$, and then 9 inch casing was run to 887 mbsf. To ensure good coupling of the strainmeter to the formation and to eliminate local fluid motion around the seismic sensors and the tiltmeter, the sensors were cemented in the open hole section below the $95 / 8$ inch casing shoe in Unit III. One pressure port was installed in the open hole within Unit IV below the strainmeter to sample pore fluid pressure in the accretionary prism. This pressure port is terminated using miniscreens to minimize the risk of clogging or fouling the hydraulic lines (Fig. F17). Above the cemented sensors in the open hole, the $95 / 8$ inch casing has screened casing joints from 757 to 780 mbsf (Fig. F16) to monitor pore fluid pressure in Unit II; this monitoring interval is hydraulically isolated from the overlying ocean by a swellable packer (Fig. F18). The downhole sensors are digitally connected to the seafloor where power is supplied and data are recovered, whereas pore fluid pressure is transmitted through hydraulic tubing to be recorded by a data logger at the wellhead (Fig. F19).

The nonhydraulic components of the observatory are all located in the deeper portion of the LTBMS assembly string (Fig. F16). The location of the strainmeter, tiltmeter, seismometers, and pressure ports for pore fluid pressure monitoring were determined based on LWD information. In the lowermost portion of the sensor package, the strainmeter is installed in a fracture-free zone. It is a volumetric strain system with a small sensing volume (Fig. F20). Above the strainmeter is an instrument carrier (Fig. F21) on which a Guralp broadband seismometer and the tilt combo package (tiltmeter, geophone, accelerometer, and thermometer string digitizer) are mounted. The thermistor string has a total length of $146 \mathrm{~m}$, with five nodes spaced over its length at predefined spacing. It is terminated at the bottom by a digitizing unit that is mounted to the top of the instrument carrier. Figure F22 shows one thermometer node protected by polyurethane and tie-wrapped to the $3 \frac{1}{2}$ inch tubing.

In total, three cables plus the flatpack umbilical run upward from the instrument carrier, together with 
the thermistor cable. Apart from the latter, everything was fed through four slits in the swellable packer's rubber compound mantle. Further above, centralizers, tie wraps, and steel bands secure the cables and umbilical to the string and feed all lines into the CORK head (Fig. F23).

Figures F23, F24, and F25 illustrate the arrangement of the wellhead (CORK head and ROV platform), showing the orientation of the pressure recorder and transducers and Teledyne Ocean Design, Inc. (ODI) connectors. Before lowering the completion string into water, all the hydraulic tubes were equilibrated to seawater pressure by opening two-way valves on Bay 1 of the CORK head to allow fluid to enter the tube and displace trapped air (see also Fig. F19). All the pressure transducers were connected to ocean by three-way valves to protect them from excess pressures and damage. After landing on the borehole but prior to cementing, all two-way valves were closed to inhibit borehole fluid flow in the hydraulic tubes, and they remained closed until after the cementing operation. When cementing was completed and the completion string was released at the running tool, we switched the three-way valves to connect the three pressure transducers to start observation of borehole formation pressure. By ROV communication, we obtained the pore pressure records from the initial $\sim 15 \mathrm{~h}$ of observation, as well as all pressure readings prior to switching the valves from the seawater port (i.e., hydrostatic pressure) to the ports at depth. The record (Fig. F26) clearly shows tidal variations with the pressure disturbance during circulation and cementing before the valves were closed. After switching the valves (after cementing was finished), we observed a shift in pressure and different tidal response from ocean, most notably for the bottom pressure port (PP1) below the cemented section near the strainmeter, suggesting that the cement has successfully isolated the bottom section of open hole from the upper portion of the casing and overlying ocean.

Before the ROV left the CORK head, the observatory was set to standby mode until future ROV visits. One exception is the CORK head-mounted pressure sensor unit, which was set to record at a 30 s interval; at the next site visit, a pore pressure record at four levels $(3 \times$ formation pressure plus seafloor reference) will be available. In summary, the health of all observatory components installed with the LTBMS can be confirmed.

In the coming year, we will download pressure data and start long-term observation with all instruments by data recorder installed in the seafloor. The data recorder has a stack of batteries that can power the whole system for $1 \mathrm{y}$. We plan to connect the observatory to the undersea Dense Oceanfloor Network System for Earthquakes and Tsunamis (DONET) submarine cable observatory network so that measurements can be observed in real time from a shore-based monitoring station during the next visit to the Site C0002 observatory in 2011 or later.

\section{Preliminary scientific assessment}

The data collected from the recovered SmartPlug proved to be complete time series data over $>15$ months and validates the concept of cheap, durable, replaceable CORK-like observatories. The upgraded version, the GeniusPlug, also adds another dimension: expandable. Data are still being evaluated from the SmartPlug, and it is anticipated that the geochemical and biological supplementary sampling systems will be as successful when the GeniusPlug is recovered.

The LTBMS CORK is one of the most ambitious CORK deployments ever. With the wide array of sensors successfully deployed and tested, we feel fairly confident that the Hole C0002G LTBMS will provide a wealth of valuable data and observations once it is tied into the DONET undersea network. The stringent and repetitive testing regime before, during, and after deployment went a long way to establishing the feasibility of deploying complex and sensitive permanent observatory systems in the NanTroSEIZE study area and give the entire project greater confidence that the future planned 7000 mbsf observatory can be successfully deployed.

These operations marked great strides forward in the NanTroSEIZE project and have provided the tools to ensure the future success of the complex drilling project.

\section{References}

Ashi, J., Kuramoto, S., Morita, S., Tsunogai, U., Goto, S., Kojima, S., Okamoto, T., Ishimura, T., Ijiri, A., Toki, T., Kudo, S., Asai, S., and Utsumi, M., 2002. Structure and cold seep of the Nankai accretionary prism off Kumano-outline of the off Kumano survey during YK01-04 Leg 2 cruise. JAMSTEC J. Deep-Sea Res., 20:1-8. (in Japanese, with abstract in English)

Ashi, J., Lallemant, S., Masago, H., and the Expedition 315 Scientists, 2008. NanTroSEIZE Stage 1A: NanTroSEIZE megasplay riser pilot. IODP Prel. Rept., 315. doi:10.2204/iodp.pr.315.2008

Bangs, N.L.B., Moore, G.F., Gulick, S.P.S., Pangborn, E.M., Tobin, H.J., Kuramoto, S., and Taira, A., 2009. Broad, weak regions of the Nankai megathrust and implications for shallow coseismic slip. Earth Planet. Sci. Lett., 284(1-2):44-49. doi:10.1016/j.epsl.2009.04.026 
Becker, K., and Davis, E.E., 2005. A review of CORK designs and operations during the Ocean Drilling Program. In Fisher, A.T., Urabe, T., Klaus, A., and the Expedition 301 Scientists, Proc. IODP, 301: College Station, TX (Integrated Ocean Drilling Program Management International, Inc.). doi:10.2204/iodp.proc.301.104.2005

Bilek, S.L., Schwartz, S.Y., and DeShon, H.R., 2003. Control of seafloor roughness on earthquake rupture behavior. Geology, 31(5):455-458 doi:10.1130/00917613(2003)031<0455:COSROE >2.0.CO;2

Expedition 326 Scientists, 2011. NanTroSEIZE Stage 3: plate boundary deep riser: top hole engineering. IODP Prel. Rept., 326. doi:10.2204/iodp.pr.326.2011

Flemings, P.B., Kano, Y., Conin, M., Saffer, D.M., Buchs, D.M., Cukur, D., Huftile, G., Kawabata, K., Moore, C., Moe, K., Toczko, S., Araki, E., McNeill, L.C., Byrne, T.B., Moore, G.F., the Expedition 319 Science Party, and Darnell, K., 2009. Architecture and along-strike variation of the Nankai megasplay fault: results from IODP Expedition 319. Eos, Trans. Am. Geophys. Union, 90(52)(Suppl.):T12A-03. (Abstract) http:// www.agu.org/meetings/fm09/waisfm09.html

Hickman, S., Zoback, M., and Ellsworth, W., 2004. Introduction to special section: preparing for the San Andreas Fault Observatory at depth. Geophys. Res. Lett., 31(12):L12S01. doi:10.1029/2004GL020688

Ike, T., Moore, G.F., Kuramoto, S., Park, J-O., Kaneda, Y., and Taira, A., 2008a. Tectonics and sedimentation around Kashinosaki Knoll: a subducting basement high in the eastern Nankai Trough. Isl. Arc, 17(3):358-375. doi:10.1111/j.1440-1738.2008.00625.x

Ike, T., Moore, G.F., Kuramoto, S., Park, J.-O., Kaneda, Y., and Taira, A., 2008b. Variations in sediment thickness and type along the northern Philippine Sea plate at the Nankai Trough. Isl. Arc, 17(3):342-357. doi:10.1111/ j.1440-1738.2008.00624.x

Kimura, G., Screaton, E.J., Curewitz, D., and the Expedition 316 Scientists, 2008. NanTroSEIZE Stage 1A: NanTroSEIZE shallow megasplay and frontal thrusts. IODP Prel. Rept., 316. doi:10.2204/iodp.pr.316.2008

Kinoshita, M., Tobin, H., Ashi, J., Kimura, G., Lallemant, S., Screaton, E.J., Curewitz, D., Masago, H., Moe, K.T., and the Expedition 314/315/316 Scientists, 2009. Proc. IODP, 314/315/316: Washington, DC (Integrated Ocean Drilling Program Management International, Inc.). doi:10.2204/iodp.proc.314315316.2009

Kinoshita, M., Tobin, H., Moe, K.T., and the Expedition 314 Scientists, 2008. NanTroSEIZE Stage 1A: NanTroSEIZE LWD transect. IODP Prel. Rept., 314. doi:10.2204/ iodp.pr.314.2008

Kodaira, S., Takahashi, N., Park, J.-O., Mochizuki, K., Shinohara, M., and Kimura, S., 2000. Western Nankai Trough seismogenic zone: results from a wide-angle ocean bottom seismic survey. J. Geophys. Res., [Solid Earth], 105(B3):5887-5905. doi:10.1029/1999JB900394

Kopf, A., Mascle, J., and Klaeschen, D., 2003. The Mediterranean Ridge: a mass balance across the fastest growing accretionary complex on Earth. J. Geophys. Res., [Solid Earth], 108:2372-2403. doi:10.1029/2001JB000473
Kopf, A., Saffer, D.M., Davis, E.E., Hammerschmidt, S., LaBonte, A., Meldrum, R., Toczko, S., Lauer, R., Heesemann, M., Macdonald, R., Wheat, C.G., Jannasch, H.W., Edwards, K., Orcutt, B., Haddad, A., Villinger, H., Araki, E., Kitada, K., Kimura, T., and Kido, Y., 2011. The SmartPlug and GeniusPlug: simple retrievable observatory systems for NanTroSEIZE borehole monitoring. In Kopf, A., Araki, E., Toczko, S., and the Expedition 332 Scientists, Proc. IODP, 332: Tokyo (Integrated Ocean Drilling Program Management International, Inc.). doi:10.2204/iodp.proc.332.105.2011

Lay, T., Kanamori, H., Ammon, C.J., Nettles, M., Ward, S.N., Aster, R.C., Beck, S.L., Bilek, S.L., Brudzinski, M.R., Butler, R., DeShon, H.R., Ekström, G., Satake, K., and Sipkin, S., 2005. The great Sumatra-Andaman earthquake of 26 December 2004. Science, 308(5725):11271133. doi:10.1126/science.1112250

Le Pichon, X., Iiyama, T., Chamley, H., Charvet, J., Faure, M., Fujimoto, H., Furuta, T., Ida, Y., Kagami, H., Lallemant, S., Leggett, J., Murata, A., Okada, H., Rangin, C., Renard, V., Taira, A., and Tokuyama, H., 1987a. Nankai Trough and the fossil Shikoku Ridge: results of Box 6 Kaiko survey. Earth Planet. Sci. Lett., 83(1-4):186-198. doi:10.1016/0012-821X(87)90065-3

Le Pichon, X., Iiyama, T., Chamley, H., Charvet, J., Faure, M., Fujimoto, H., Furuta, T., Ida, Y., Kagami, H., Lallemant, S., Leggett, J., Murata, A., Okada, H., Rangin, C., Renard, V., Taira, A., and Tokuyama, H., 1987b. The eastern and western ends of Nankai Trough: results of Box 5 and Box 7 Kaiko survey. Earth Planet. Sci. Lett., 83(1-4):199-213. doi:10.1016/0012-821X(87)90066-5

$\mathrm{Ma}, \mathrm{K} ., 2005$. Slip zone and energetic of a large earthquake from seismological modeling and fault core of TCDP. Eos, Trans. Am. Geophys. Union, 86(52):T43D-02. (Abstract) http://www.agu.org/meetings/fm05/ waisfm05.html

Mazzotti, S., Le Pichon, X., Henry, P., and Miyazaki, S.-I., 2000. Full interseismic locking of the Nankai and JapanWest Kuril subduction zones: an analysis of uniform elastic strain accumulation in Japan constrained by permanent GPS. J. Geophys. Res., [Solid Earth], 105(B6):13159-13178. doi:10.1029/2000JB900060

Miyazaki, S., and Heki, K., 2001. Crustal velocity field of southwest Japan: subduction and arc-arc collision. J. Geophys. Res., [Solid Earth], 106(B3):4305-4326. doi:10.1029/2000JB900312

Moore, G.F., Bangs, N.L., Taira, A., Kuramoto, S., Pangborn, E., and Tobin, H.J., 2007. Three-dimensional splay fault geometry and implications for tsunami generation. Science, 318(5853):1128-1131. doi:10.1126/science. 1147195

Moore, G.F., Park, J.-O., Bangs, N.L., Gulick, S.P., Tobin, H.J., Nakamura, Y., Sato, S., Tsuji, T., Yoro, T., Tanaka, H., Uraki, S., Kido, Y., Sanada, Y., Kuramoto, S., and Taira, A., 2009. Structural and seismic stratigraphic framework of the NanTroSEIZE Stage 1 transect. In Kinoshita, M., Tobin, H., Ashi, J., Kimura, G., Lallemant, S., Screaton, E.J., Curewitz, D., Masago, H., Moe, K.T., and the Expedition 314/315/316 Scientists, Proc. IODP, 314/315/316: Washington, DC (Integrated Ocean 
Drilling Program Management International, Inc.). doi:10.2204/iodp.proc.314315316.102.2009

Moore, G.F., Taira, A., Klaus, A., et al., 2001. Proc. ODP, Init. Repts., 190: College Station, TX (Ocean Drilling Program). doi:10.2973/odp.proc.ir.190.2001

Nakanishi, A., Kodaira, S., Miura, S., Ito, A., Sato, T., Park, J.-O., Kido, Y., and Kaneda, Y., 2008. Detailed structural image around splay-fault branching in the Nankai subduction seismogenic zone: results from a high-density ocean bottom seismic survey. J. Geophys. Res., [Solid Earth], 113(B3):B03105. doi:10.1029/2007JB004974

Nakanishi, A., Takahashi, N., Park, J.-O., Miura, S., Kodaira, S., Kaneda, Y., Hirata, N., Iwasaki, T., and Nakamura, M., 2002. Crustal structure across the coseismic rupture zone of the 1944 Tonankai earthquake, the central Nankai Trough seismogenic zone. J. Geophys. Res., [Solid Earth], 107:2007-2027. doi:10.1029/2001JB000424

Obana, K., Kodaira, S., Mochizuki, K., and Shinohara, M., 2001. Micro-seismicity around the seaward updip limit of the 1946 Nankai earthquake dislocation area. Geophys. Res. Lett., 28(12):2333-2336. doi:10.1029/ 2000GL012794

Park, J.-O., Tsuru, T., Kodaira, S., Cummins, P.R., and Kaneda, Y., 2002. Splay fault branching along the Nankai subduction zone. Science, 297(5584):1157-1160. doi:10.1126/science.1074111

Park, J.-O., Tsuru, T., No, T., Takizawa, K., Sato, S., and Kaneda, Y., 2008. High-resolution 3D seismic reflection survey and prestack depth imaging in the Nankai Trough off southeast Kii Peninsula. Butsuri Tansa, 61:231-241. (in Japanese, with abstract in English)

Saffer, D., McNeill, L., Byrne, T., Araki, E., Toczko, S., Eguchi, N., Takahashi, K., and the Expedition 319 Scientists, 2010. Proc. IODP, 319: Tokyo (Integrated Ocean Drilling Program management International, Inc.). doi:10.2204/iodp.proc.319.2010

Saito, S., Underwood, M.B., Kubo, Y., and the Expedition 322 Scientists, 2010. Proc. IODP, 322: Tokyo (Integrated
Ocean Drilling Program management International, Inc.). doi:10.2204/iodp.proc.322.2010

Seno, T., Stein, S., and Gripp, A.E., 1993. A model for the motion of the Philippine Sea plate consistent with NUVEL-1 and geological data. J. Geophys. Res., [Solid Earth], 98(B10):17941-17948. doi:10.1029/93JB00782

Strasser, M., Moore, G.F., Kimura, G., Kitamura, Y., Kopf, A.J., Lallemant, S., Park, J.-O., Screaton, E.J., Su, X., Underwood, M.B., and Zhao, X., 2009. Origin and evolution of a splay fault in the Nankai accretionary wedge. Nat. Geosci., 2(9):648-652. doi:10.1038/ngeo609

Taira, A., Hill, I., Firth, J.V., et al., 1991. Proc. ODP, Init. Repts., 131: College Station, TX (Ocean Drilling Program). doi:10.2973/odp.proc.ir.131.1991

Tobin, H.J., and Kinoshita, M., 2006a. Investigations of seismogenesis at the Nankai Trough, Japan. IODP Sci. Prosp., NanTroSEIZE Stage 1. doi:10.2204/ iodp.sp.nantroseize 1.2006

Tobin, H.J., and Kinoshita, M., 2006b. NanTroSEIZE: the IODP Nankai Trough Seismogenic Zone Experiment. Sci. Drill., 2:23-27. doi:10.2204/iodp.sd.2.06.2006

Wang, K., and Davis, E.E., 1996. Theory for the propagation of tidally induced pore pressure variations in layered subseafloor formations. J. Geophys. Res., [Solid Earth], 101(B5):11483-11495. doi:10.1029/96JB00641

Wang, K., and Hu, Y., 2006. Accretionary prisms in subduction earthquake cycles: the theory of dynamic Coulomb wedge. J. Geophys. Res., [Solid Earth], 111(B6):B06410B06425. doi:10.1029/2005JB004094

Yamano, M., Kinoshita, M., Goto, S., and Matsubayashi, O., 2003. Extremely high heat flow anomaly in the middle part of the Nankai Trough. Phys. Chem. Earth, 28(911):487-497. doi:10.1016/S1474-7065(03)00068-8

Publication: 11 December 2011 MS 332-101 
Figure F1. Map of Nankai accretionary complex off Kumano, showing NanTroSEIZE drill sites. Stars = epicenter of great earthquakes, red circles $=$ Expedition 332 sites, green squares= previous NanTroSEIZE drill sites, black contours $=$ estimated slip during the 1944 event $(0.5 \mathrm{~m}$ interval), and area circled by dashed red line $=$ occurrence of very low frequency events. Inset shows location of Nankai Trough region in relation to Japan.

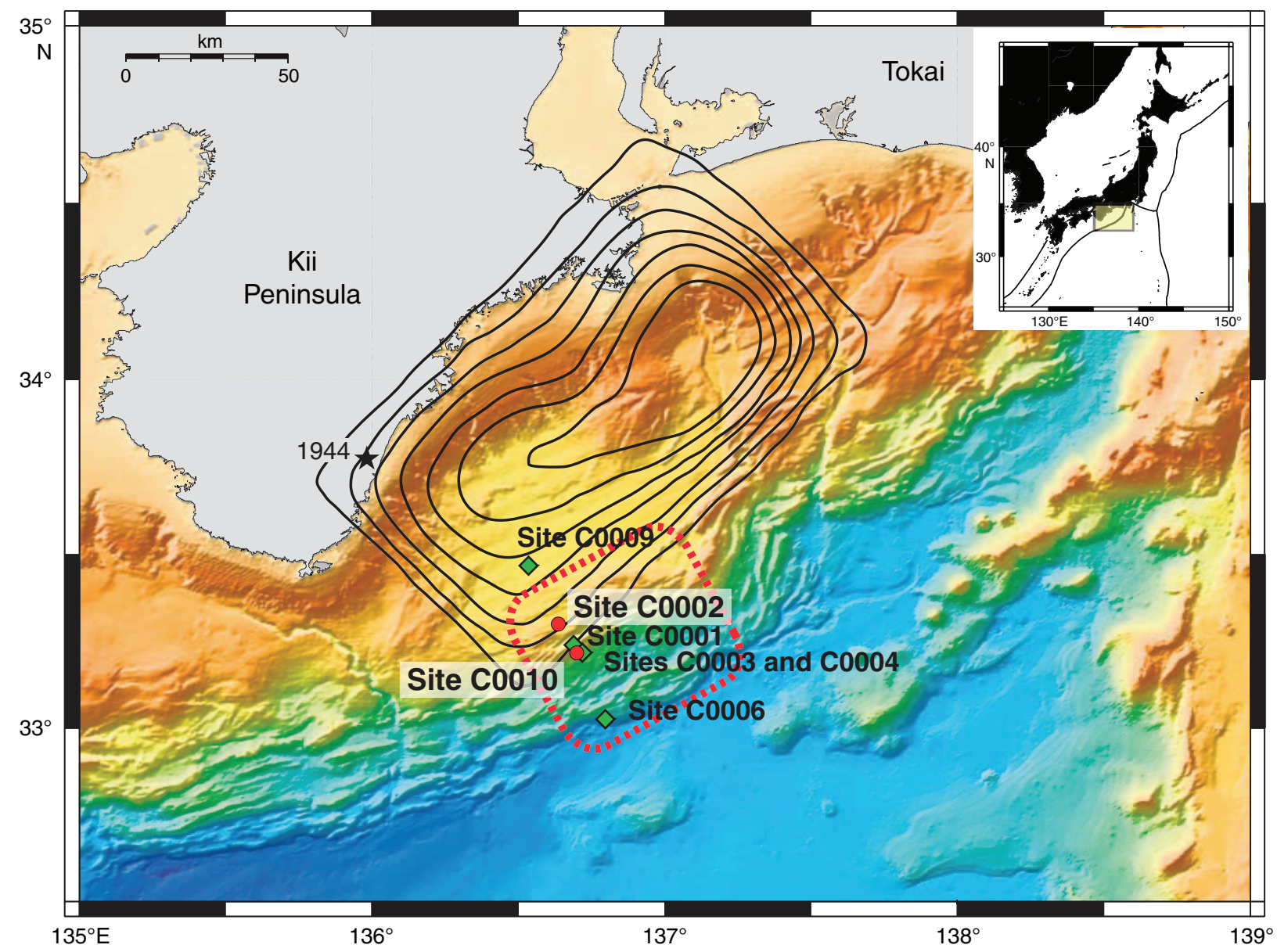


Figure F2. Spliced composite profile of a representative depth section from the NanTroSEIZE 3-D seismic data volume (Moore et al., 2009) and Line 95 from IFREE mini-3-D seismic survey (Park et al., 2008). Positions of Stage 1 and 2 drilling sites, including Sites C0002 and C0010, are depicted.
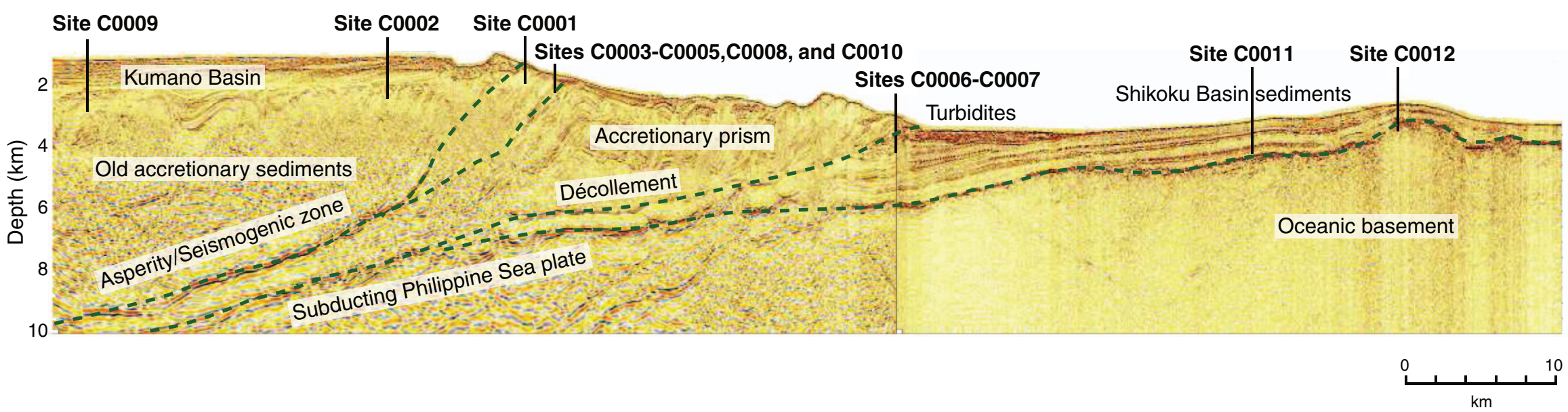
Figure F3. A. Seismic data for Site C0010 summarizing interpreted LWD information from Expedition 319 (Saffer, McNeill, Byrne, Araki, Toczko, Eguchi, Takahashi, and the Expedition 319 Scientists, 2010). See text. Key elements of casing and hole suspension are shown at right: blue = casing screens, black = casing shoe, thin black = retrievable packer, thin red $=$ SmartPlug. (Continued on next page.)

A

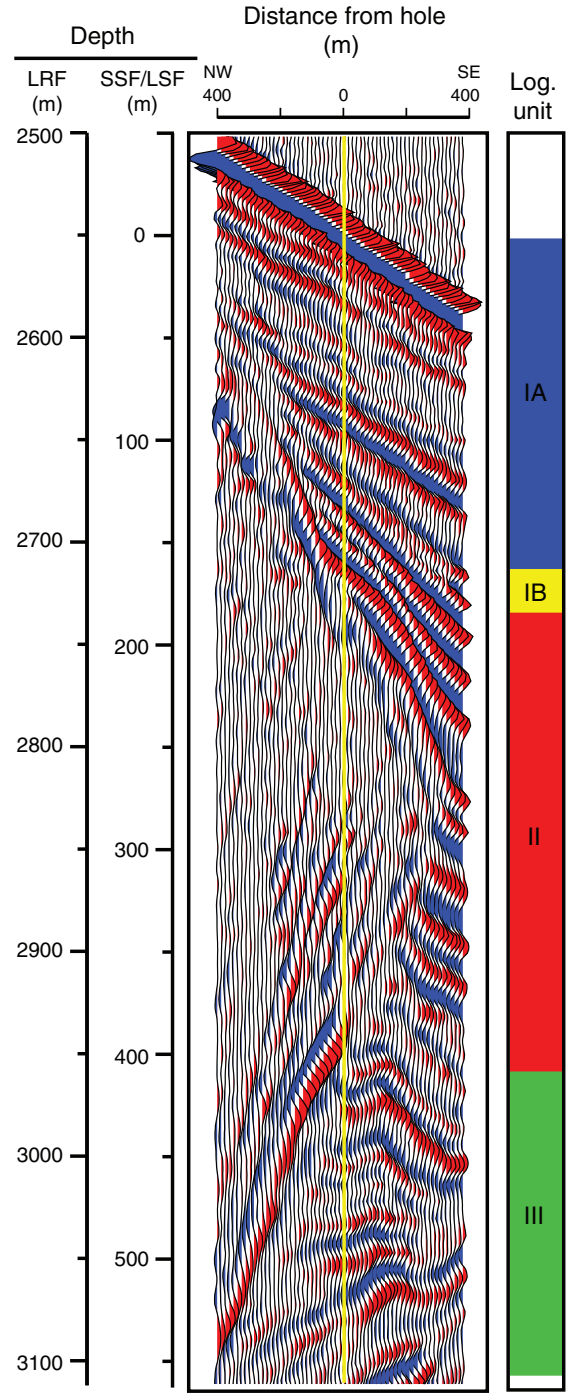

Gamma ray

Bit resistivity Ring resistivity

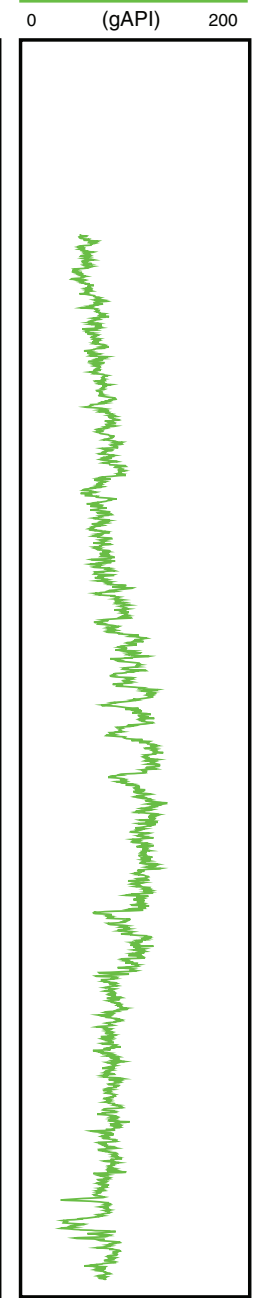
Ring resistivity

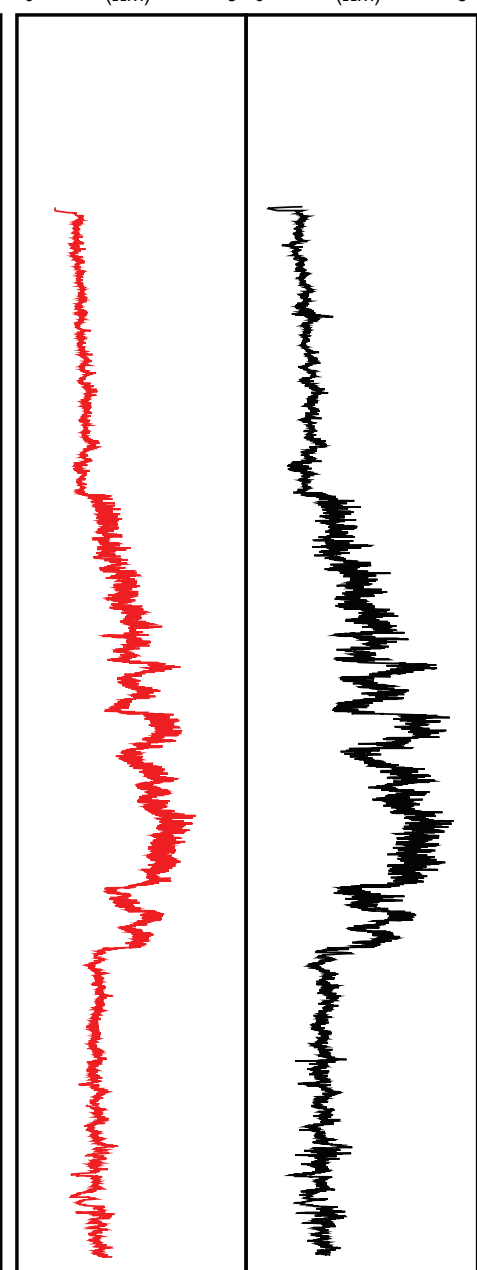

Resistivity image Resistivity image (static)

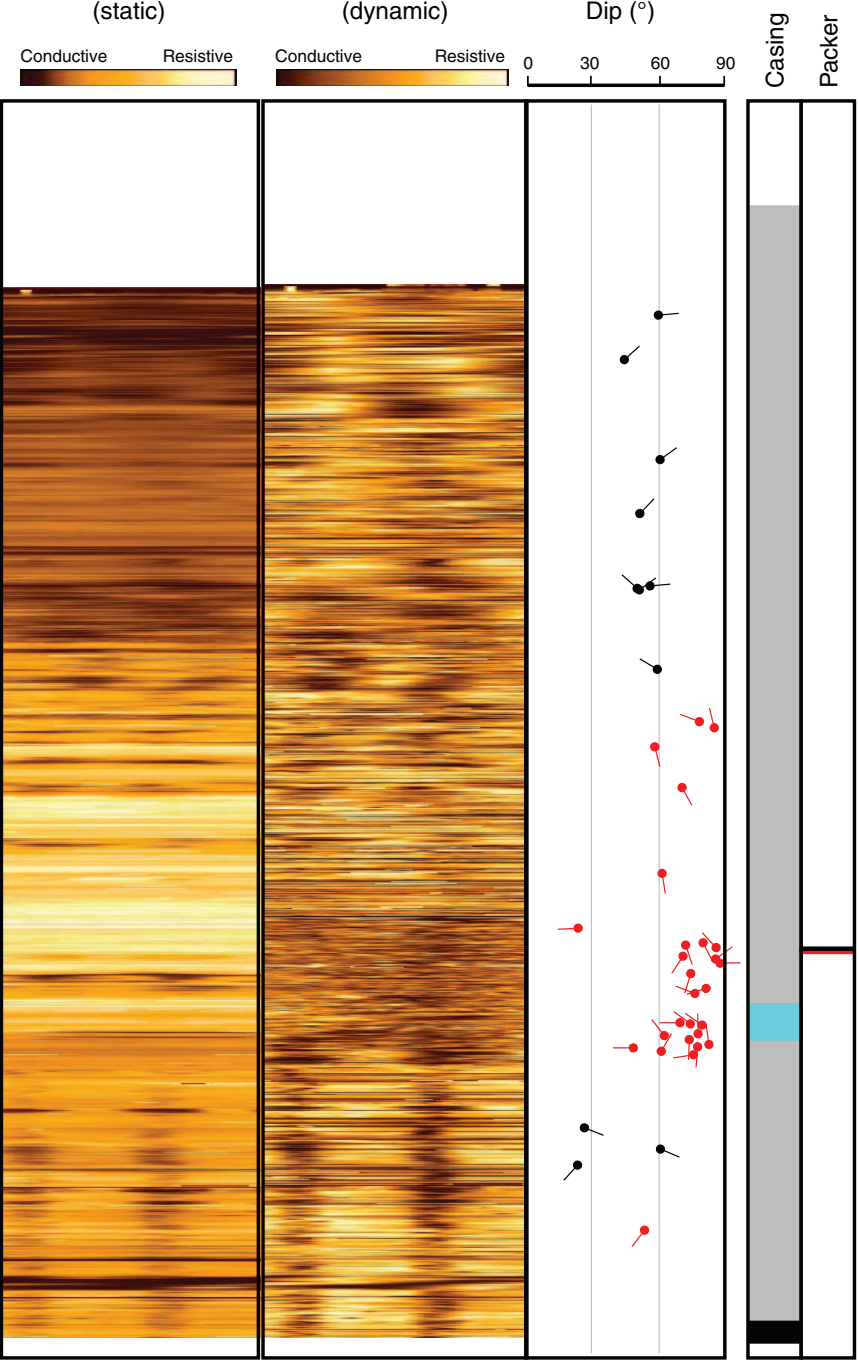

Strata $\bullet$ Fractures o 
Figure F3 (continued). B. Seismic data for Site C0002 summarizing interpreted LWD information from Expeditions 314 and 315 (Kinoshita, Tobin, Ashi, Kimura, Lallemant, Screaton, Curewitz, Masago, Moe, and the Expedition 314/315/316 Scientists, 2009). See text. LSF $=$ LWD depth below seafloor, $\mathrm{VE}=$ vertical exaggeration, $\mathrm{PEF}=$ photoelectric factor. Black tadpoles $=$ bedding, red tadpoles $=$ fracture, tadpole line $=$ dip direction of plane.

B Medium resistivity image

\section{Hole location} $\begin{array}{lll}\text { In-line } 2529 & \\ \text { NW VE }=4 & 350 \mathrm{~m} & \text { Log. } \\ \text { SE } & & \text { unit }\end{array}$

\begin{tabular}{ccc} 
Conductive & & Resistive \\
N & E S S W N & N \\
\hline
\end{tabular}

Gamma ray $\underbrace{}_{20 \quad(\text { Ring resisitivity }}$

Resistivity-

Structural data
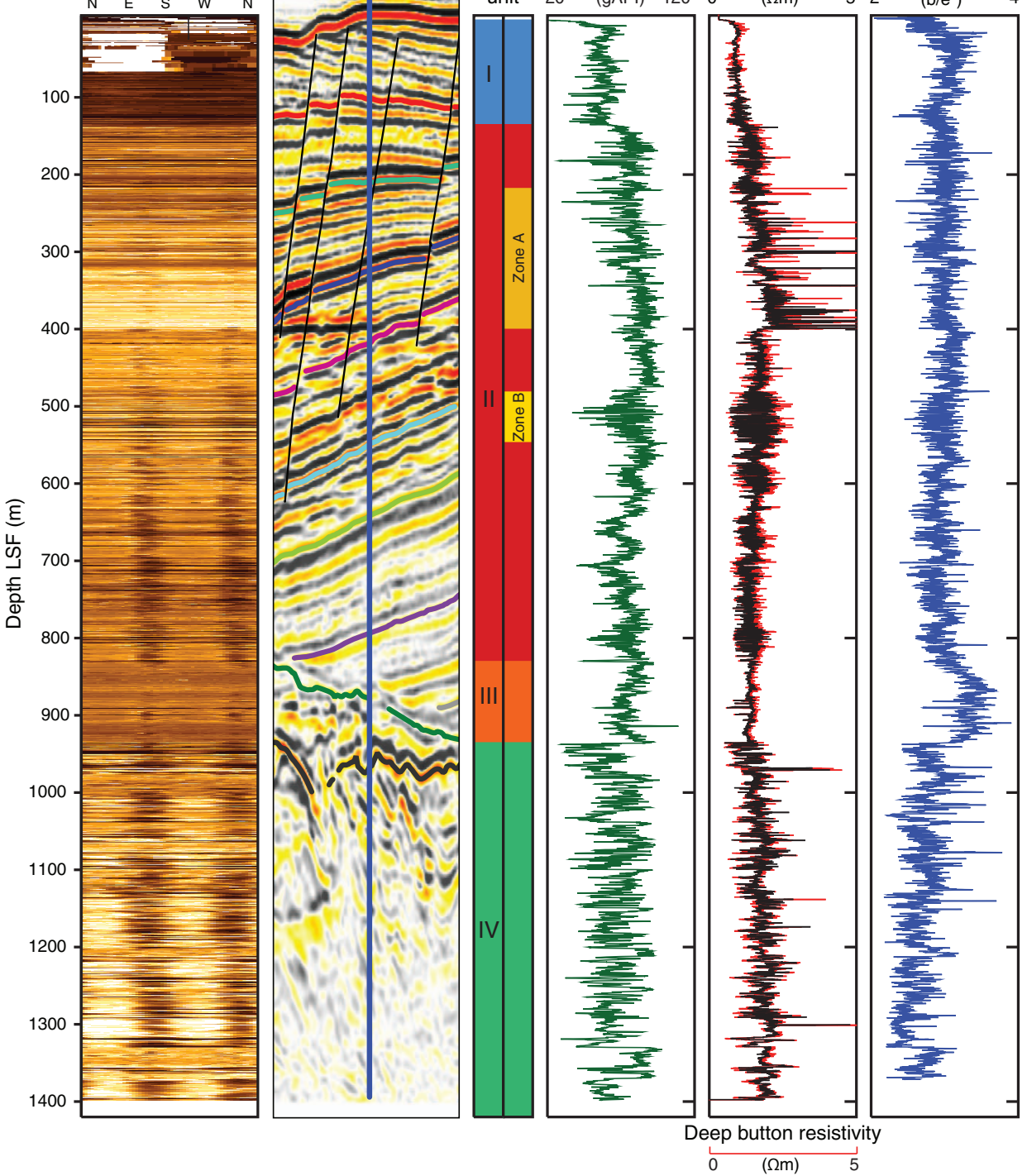

Neutron porosity
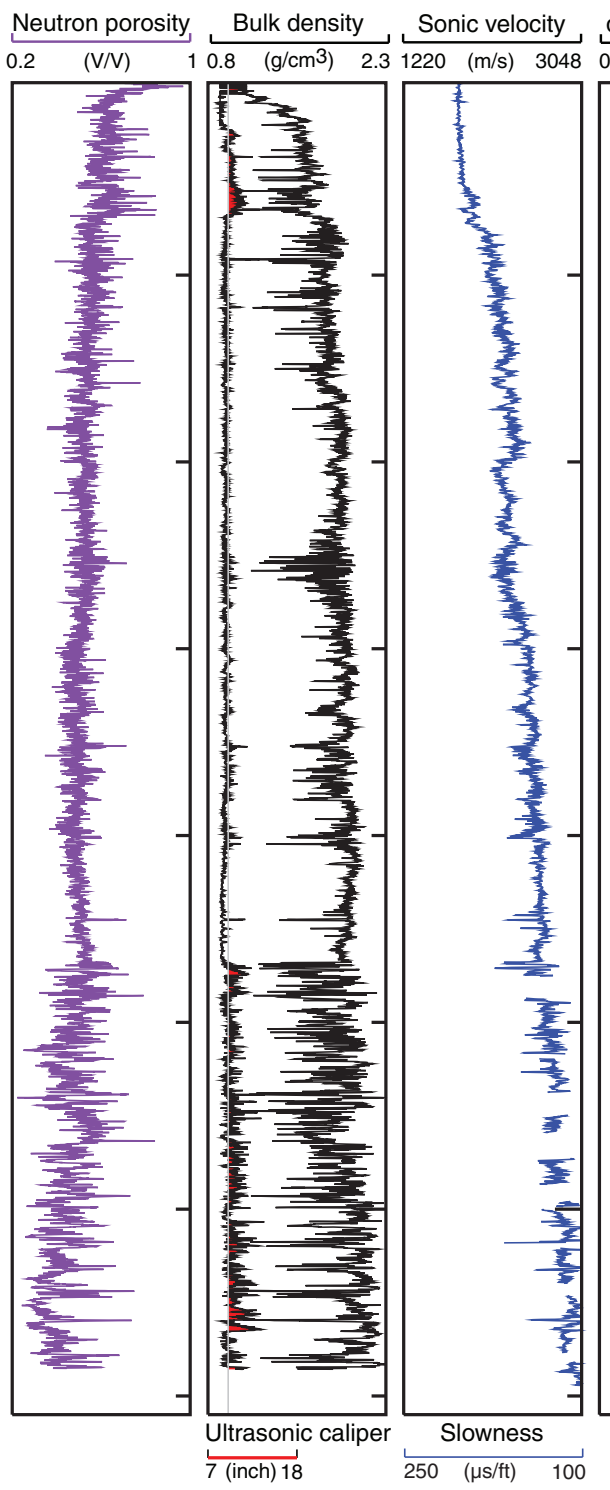

(V/N) 1000
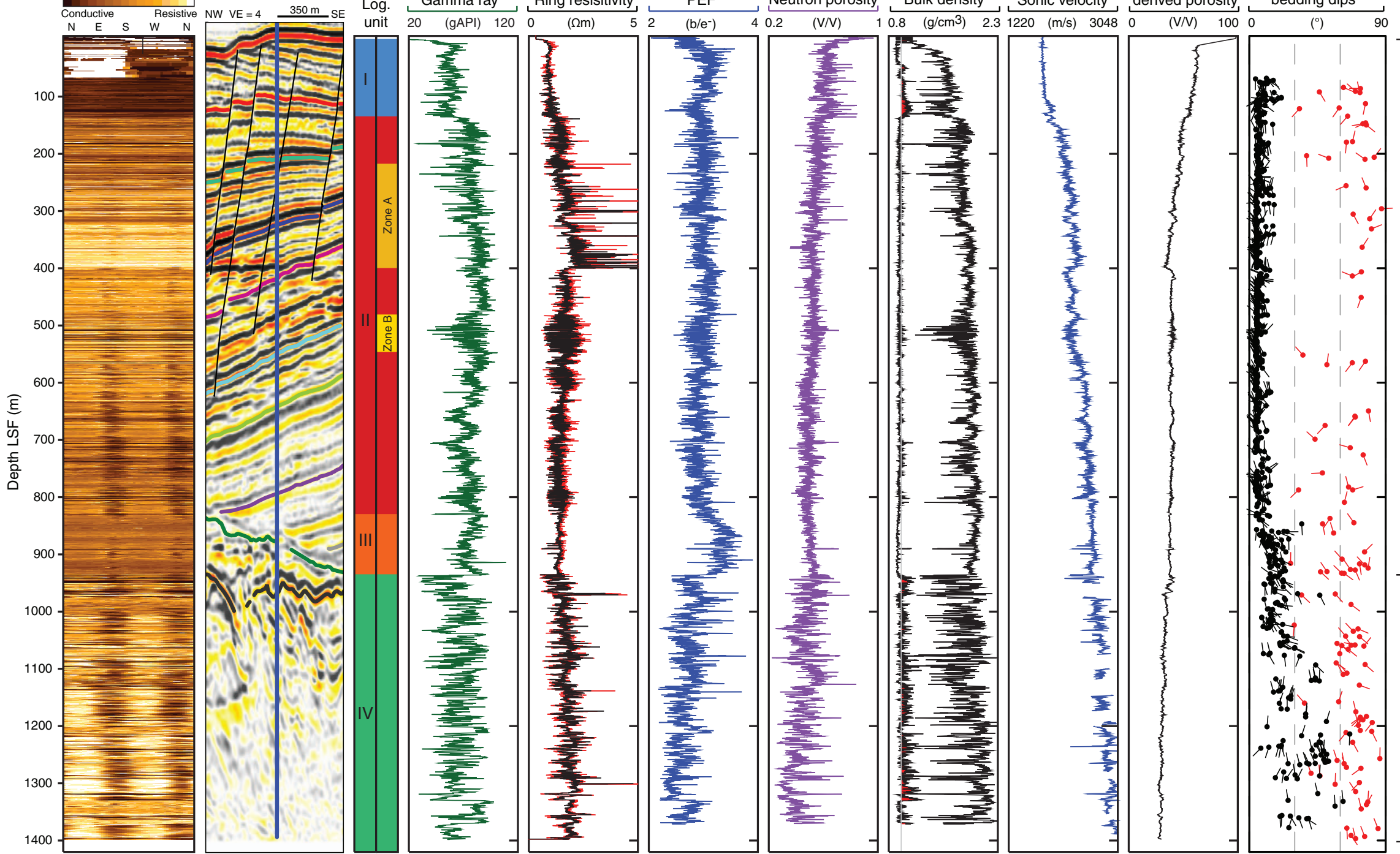

$0 \quad(\Omega \mathrm{m})$

7 (inch) 18

$250 \quad(\mu \mathrm{s} / \mathrm{ft}) \quad 100$

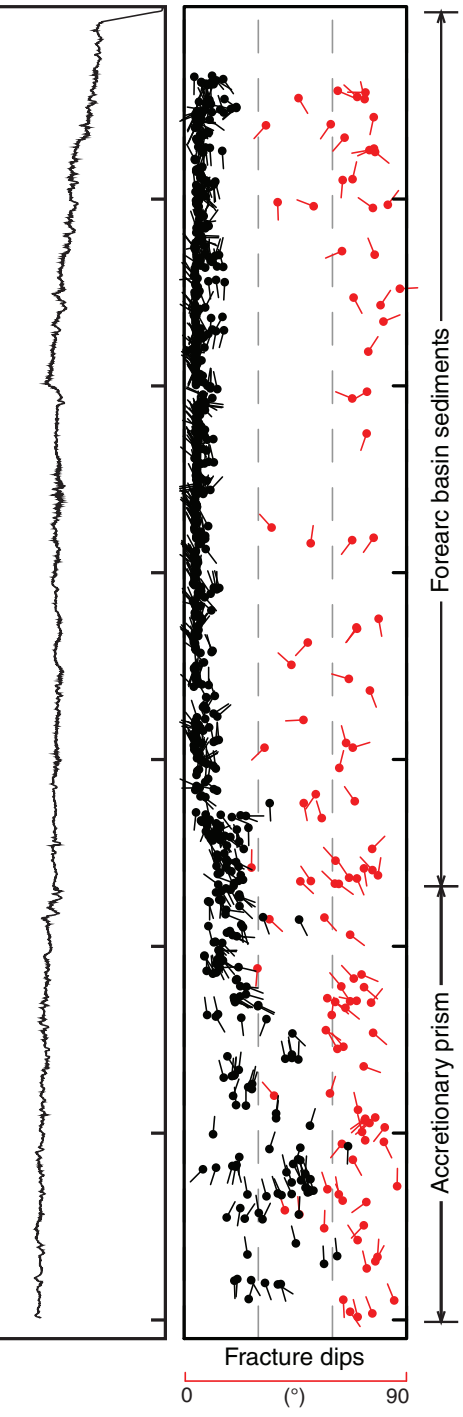


Figure F4. Hole completion at Site C0010, Expedition 319 (SmartPlug) vs. Expedition 332 (GeniusPlug). Packer depth for Expedition 332 changed.

Expedition 319 completion

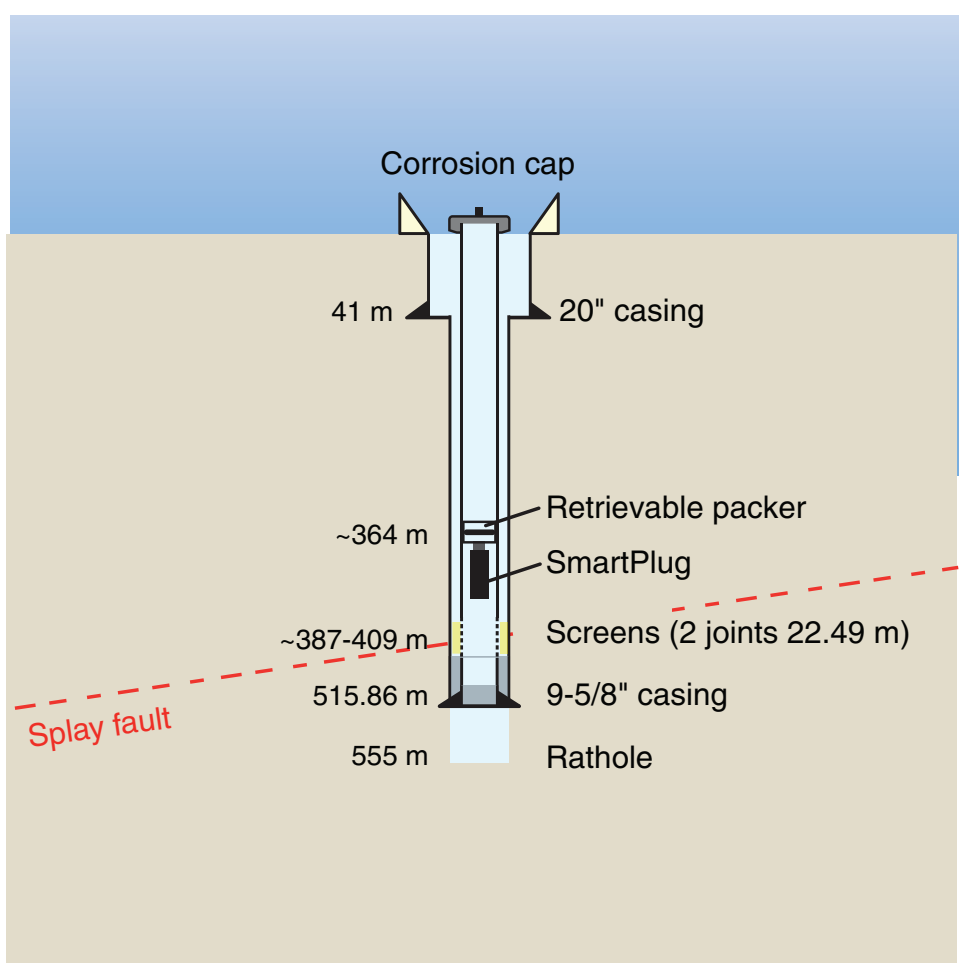

Expedition 332 completion

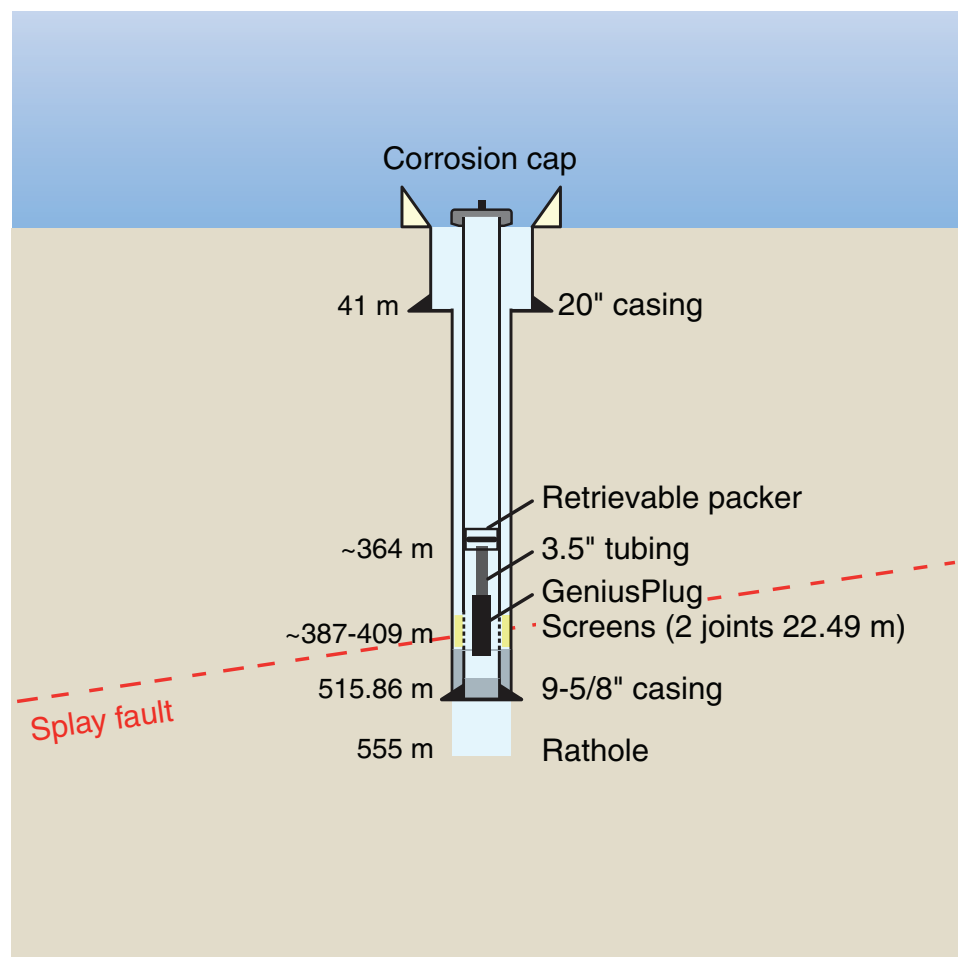


Figure F5. SmartPlug diagram as deployed in 2009. MTL = miniature temperature logger, PPC = pressure period counter.

A

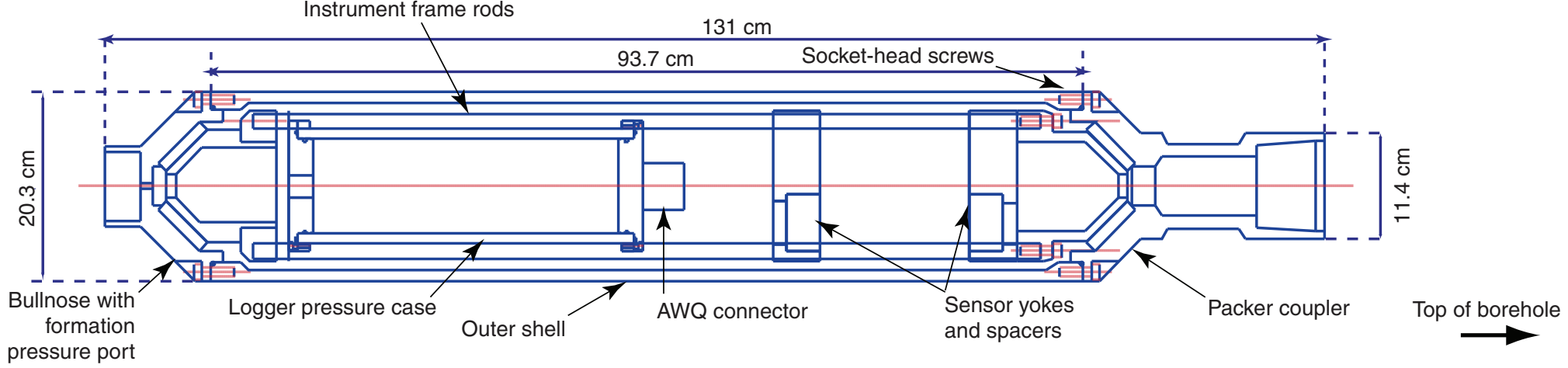

B

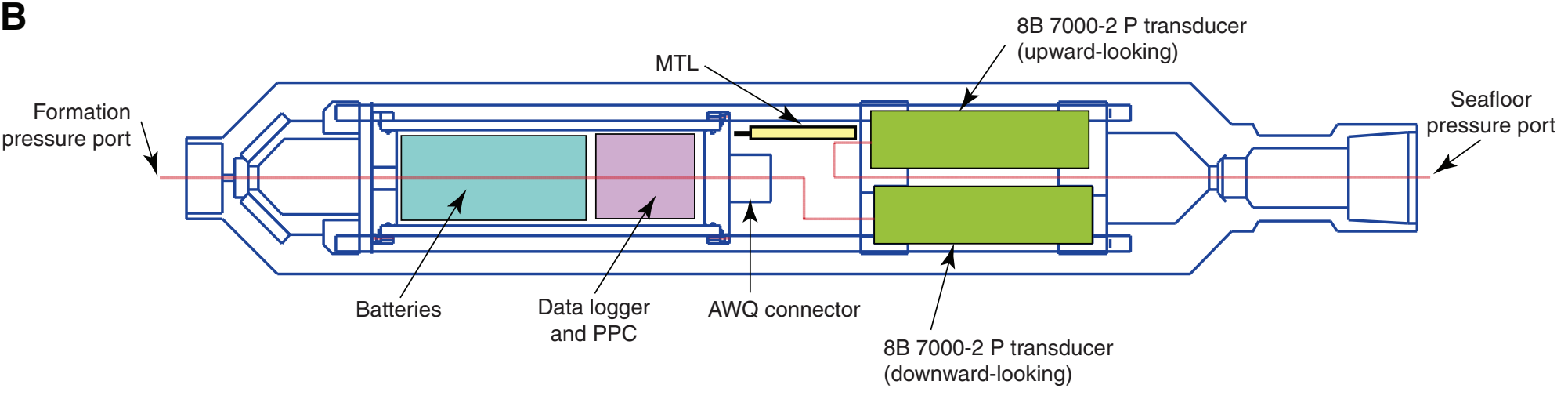


Figure F6. SmartPlug after recovery on deck.

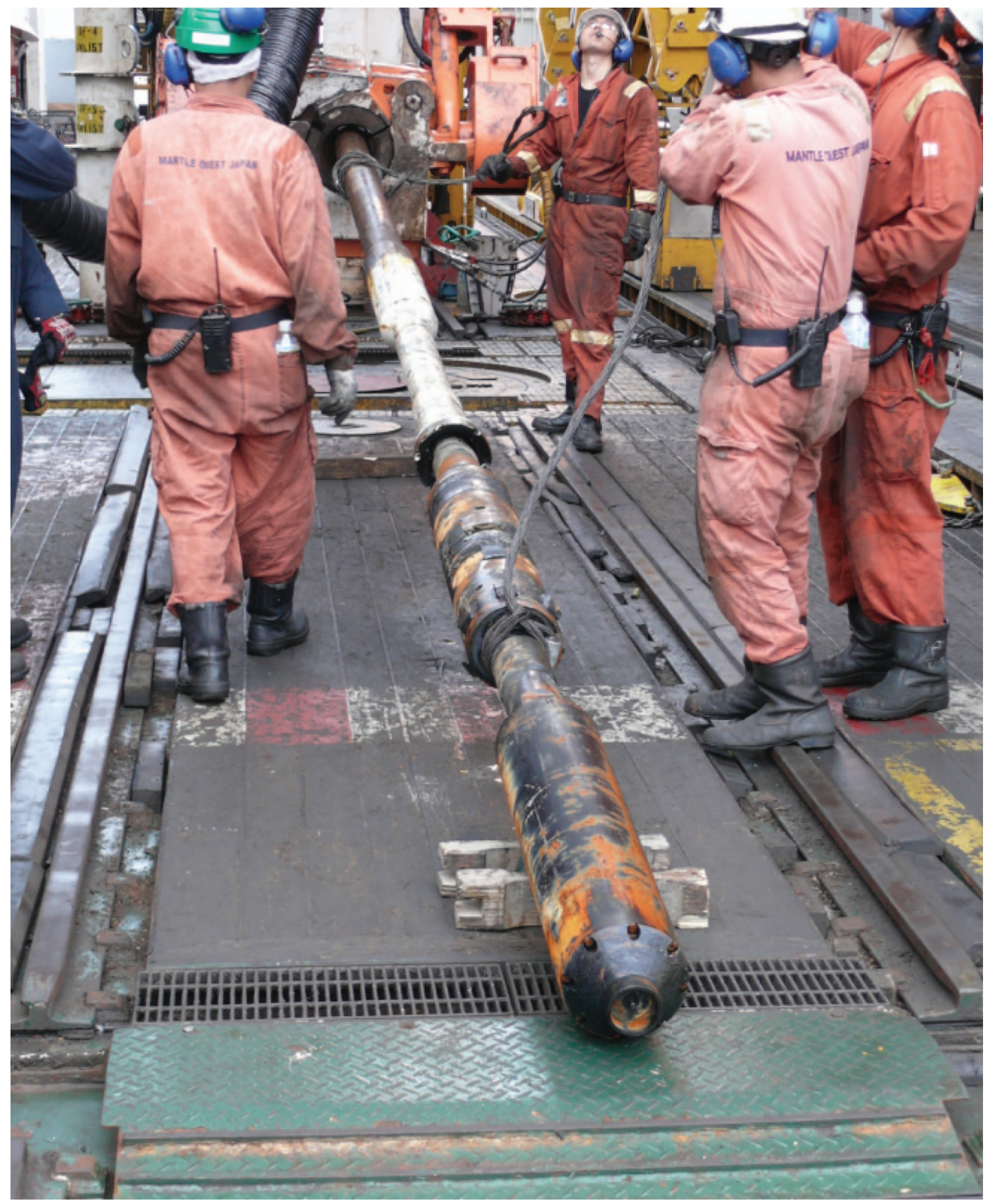



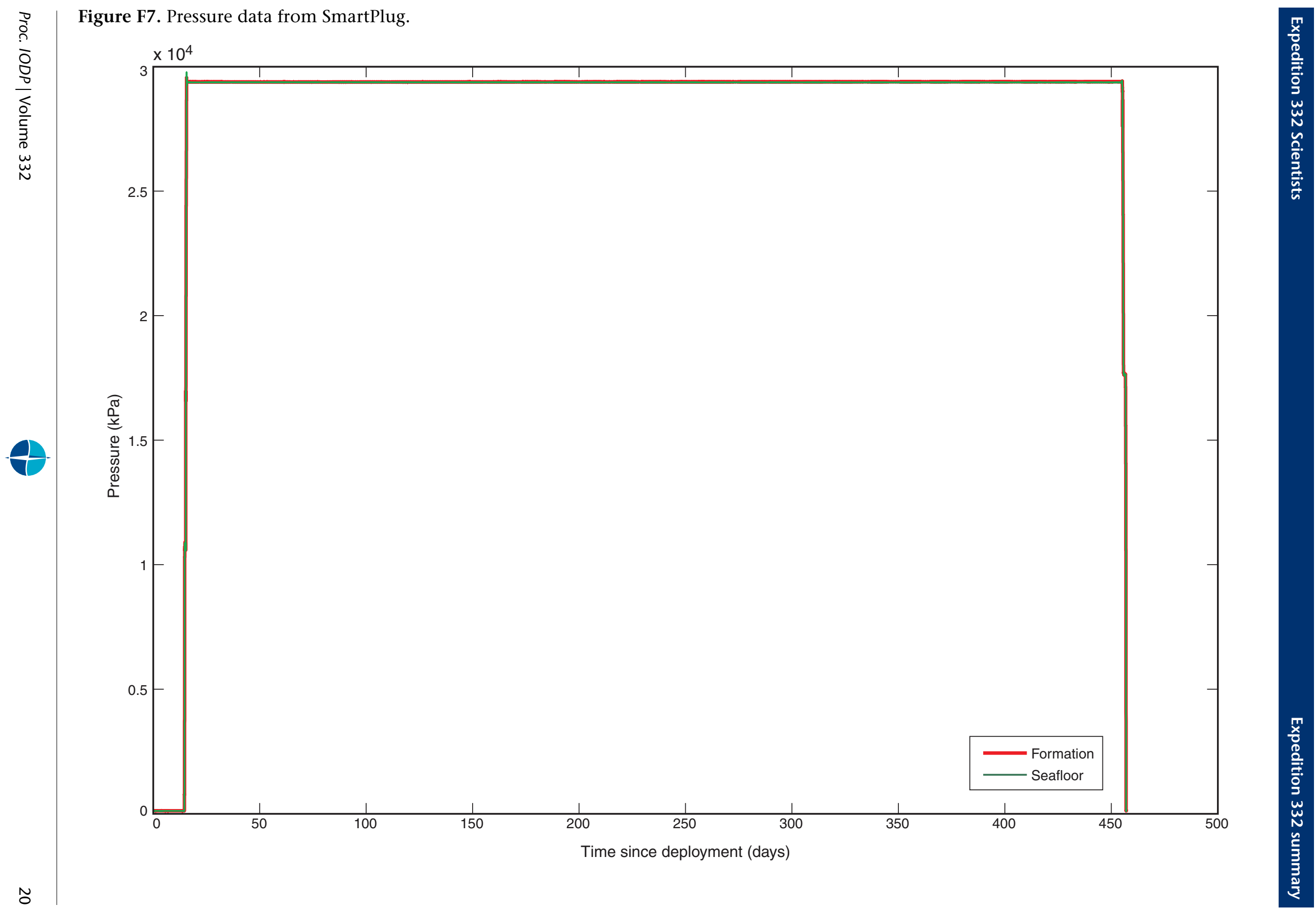

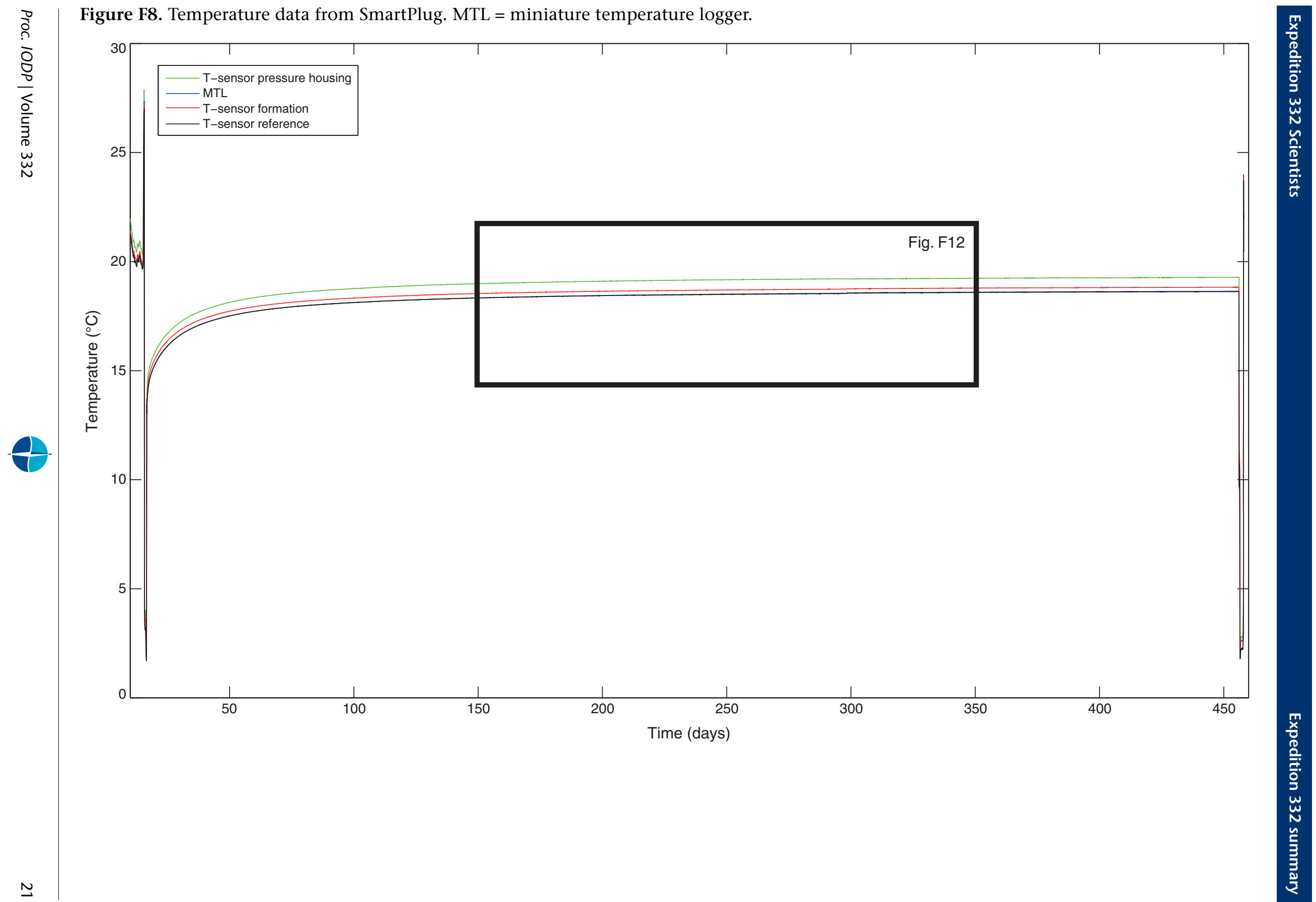
Figure F9. Pressure record from SmartPlug prior to retrieval. Note that the perturbations in the upward-looking sensor and the stable signal in the downward-looking sensor attest that the bridge plug sealed the hole effectively.

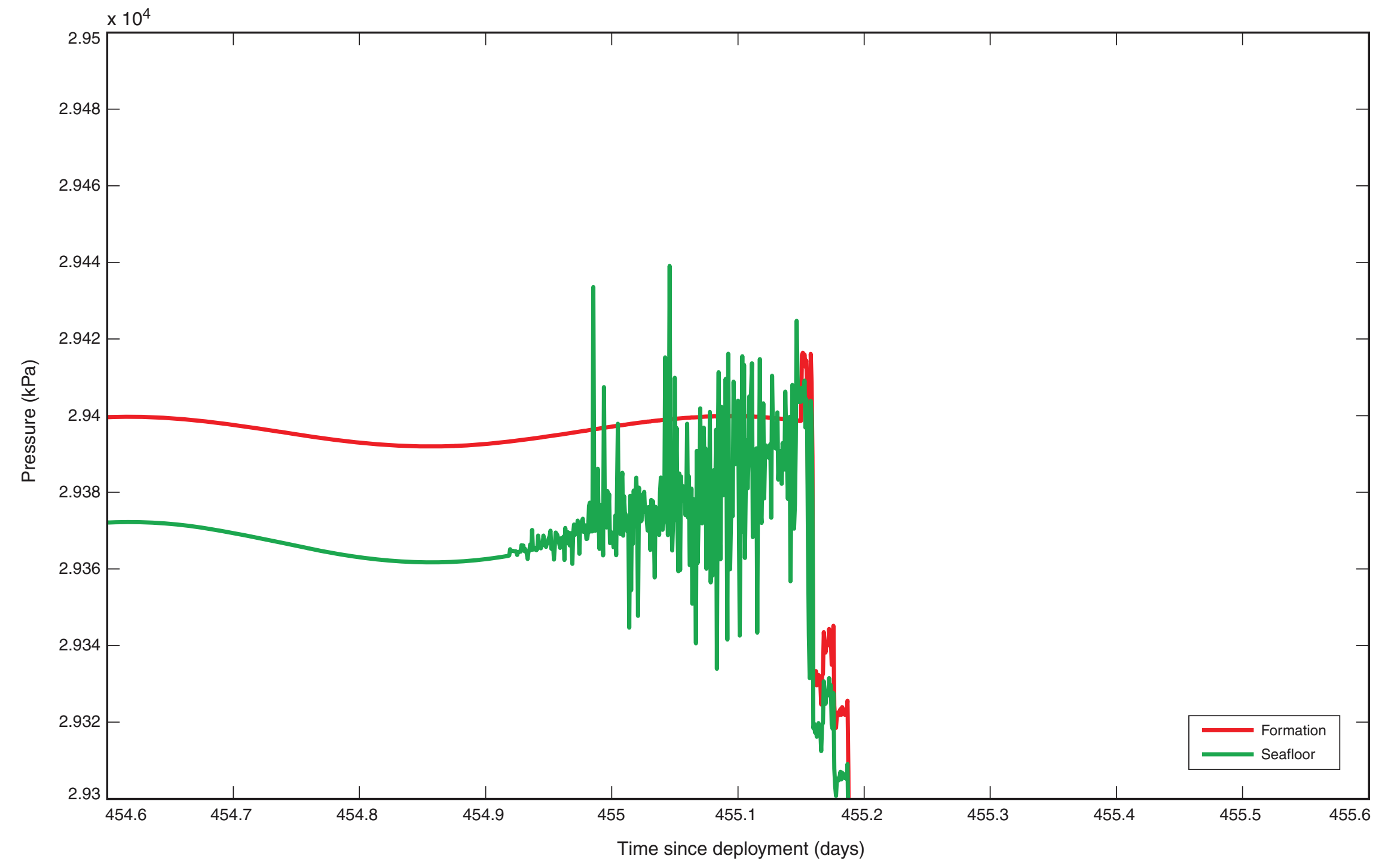




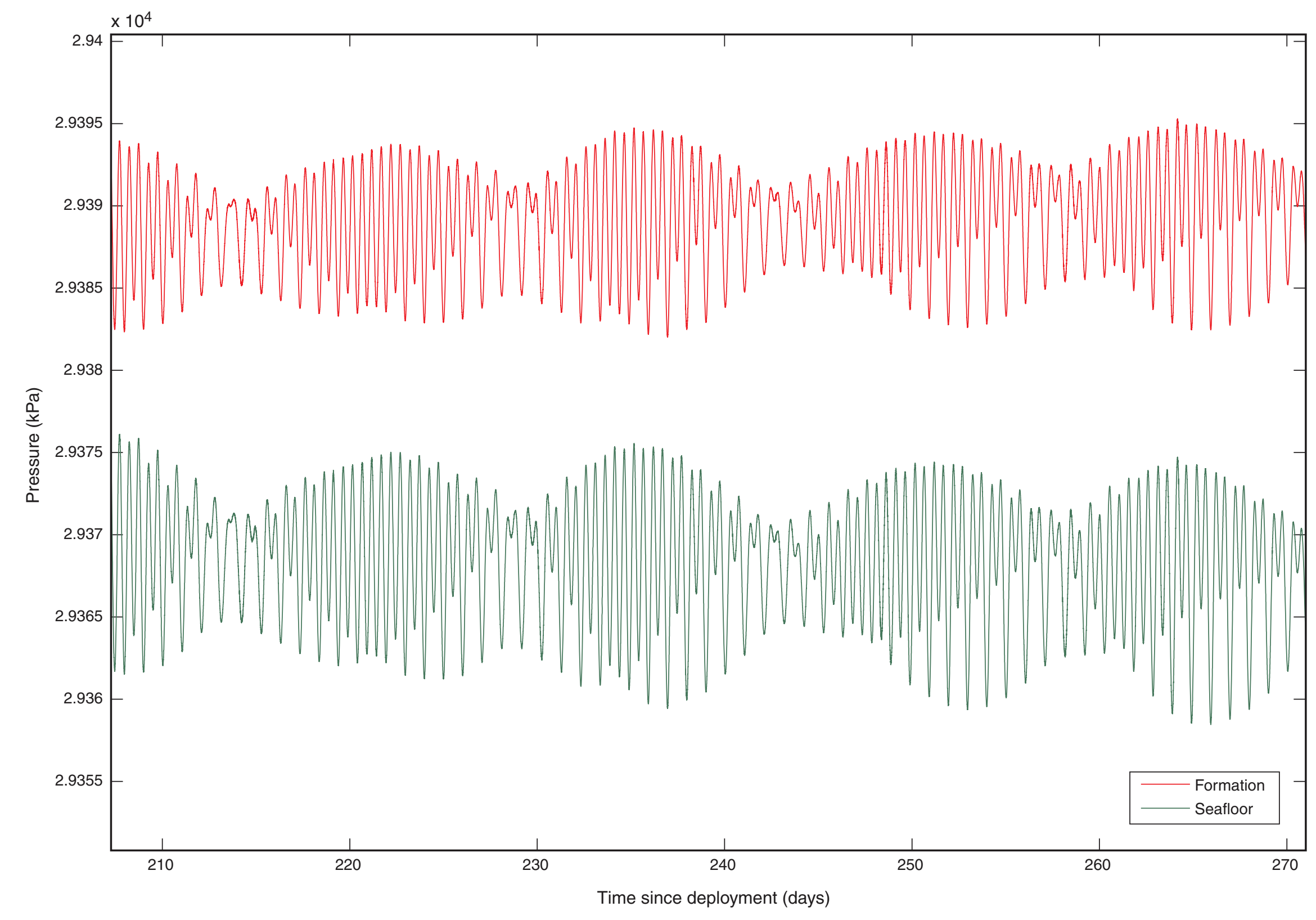


Figure F11. Example of loading to formation by the Chile M 8.8 earthquake (EQ) on 27 December 2010, followed by a tsunami approximately one day later. See text.

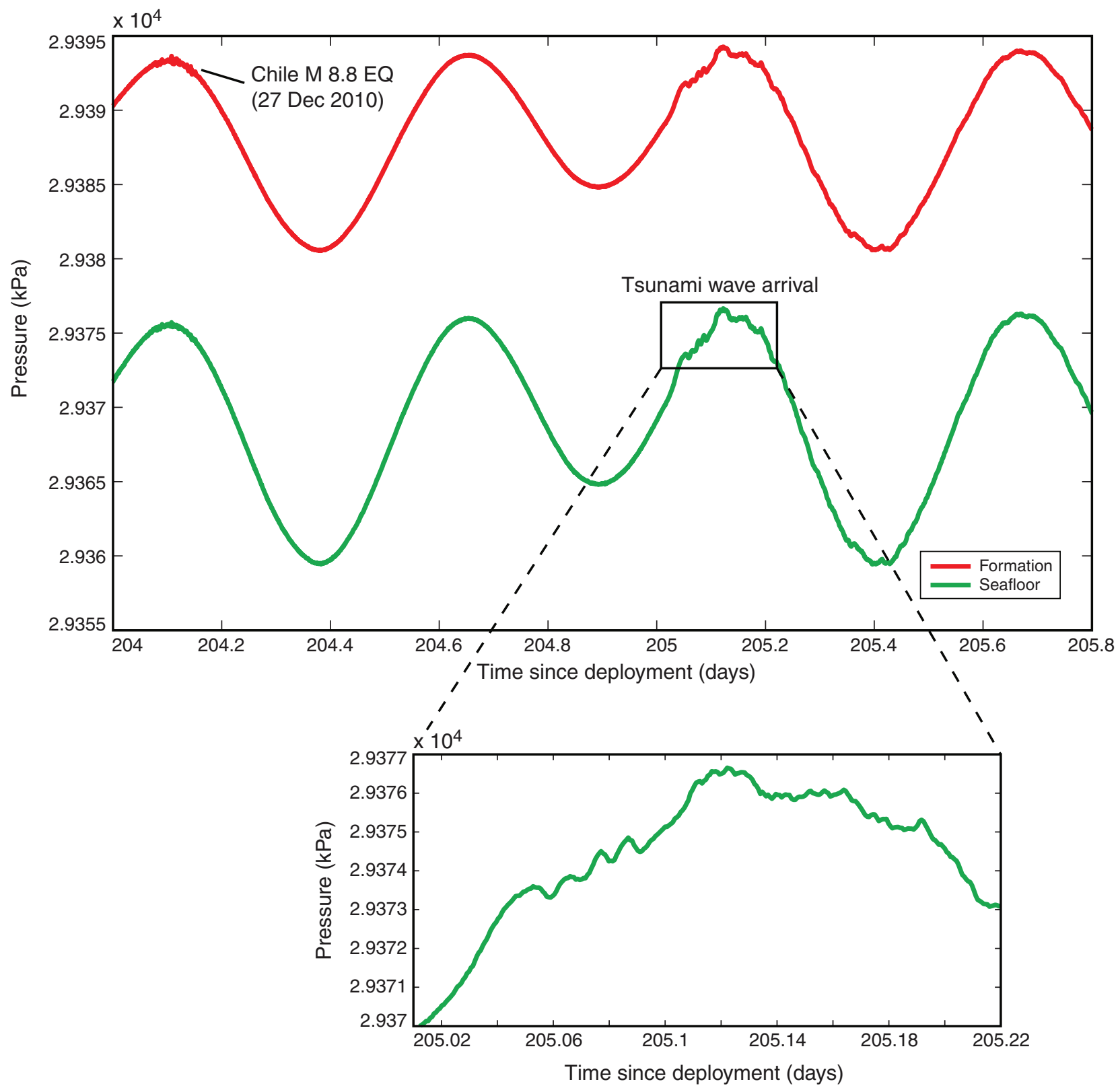


Figure F12. Example of temperature perturbations in late May 2010. It remains unresolved why three thermistors show a systematic increase by $\sim 0.03^{\circ} \mathrm{C}$ whereas one drops gently at the same time. MTL $=$ miniature temperature logger.

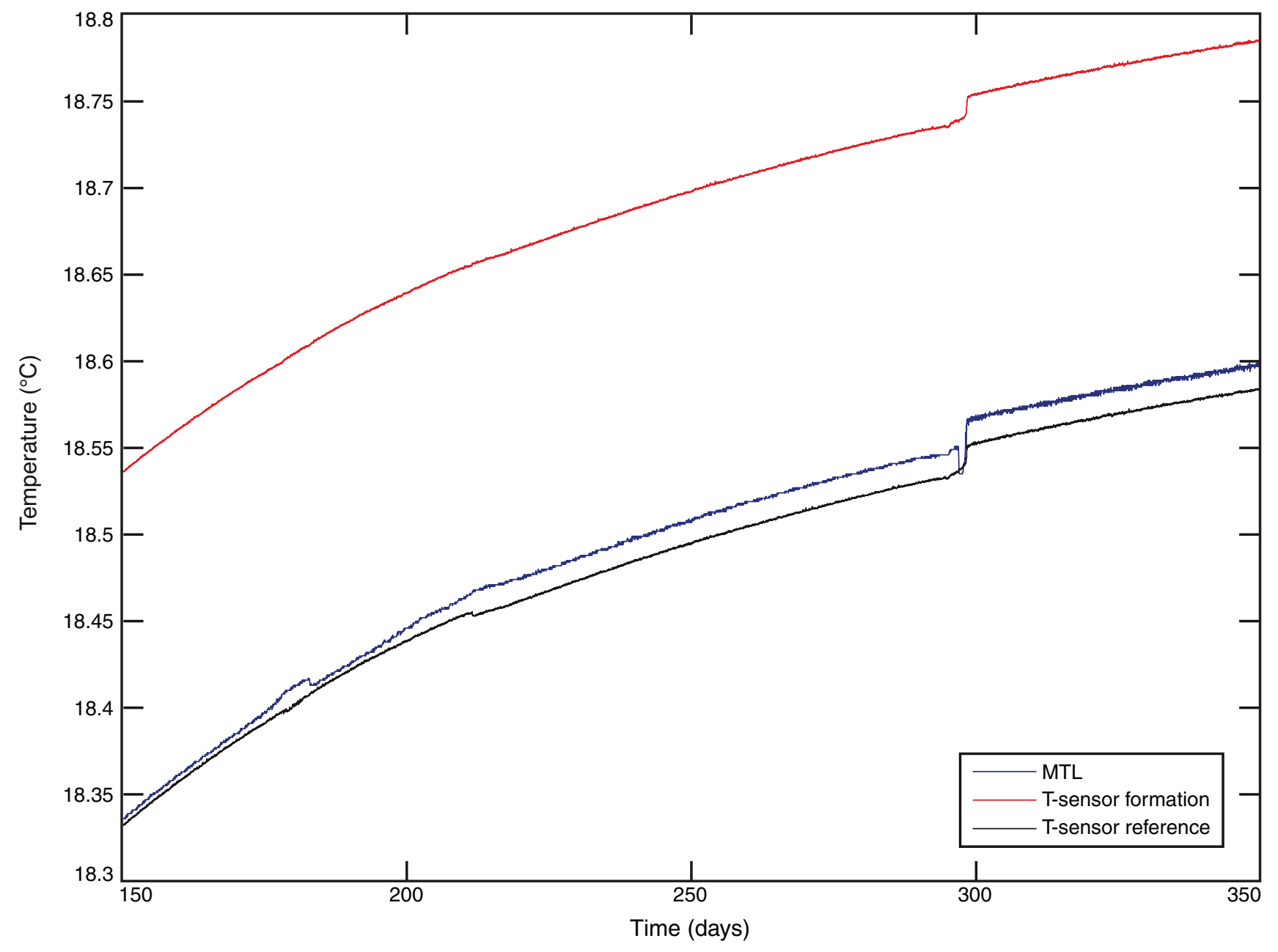


Figure F13. Photograph of ropes attached to the drill string in order to suppress VIV.

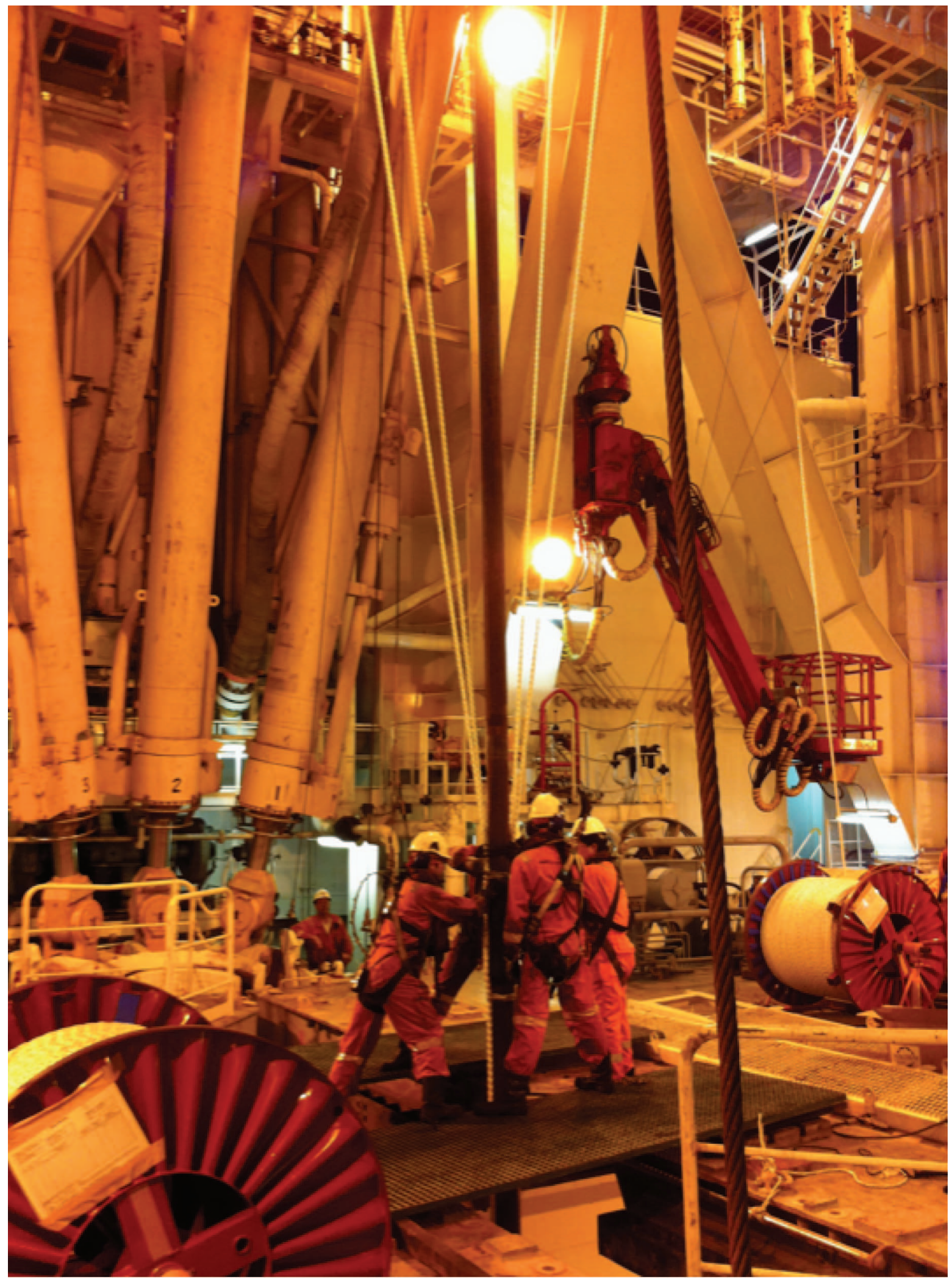


Figure F14. Example of accelerometer data illustrating the effect of the ropes on VIV on the drill string. Yellow shading $=$ data during drifting.
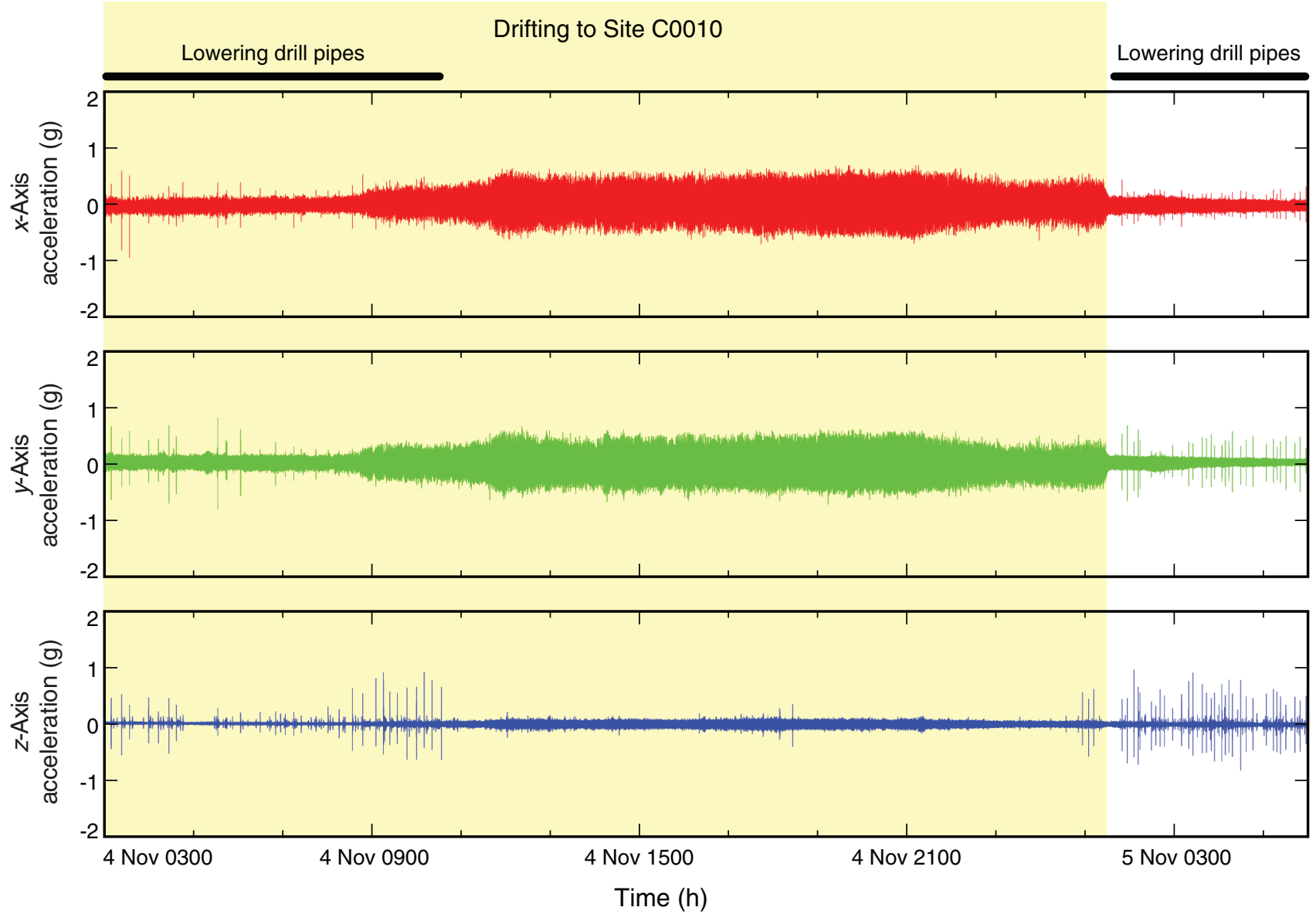
Figure F15. A. Schematic diagram of the extension unit that transformed the SmartPlug into a GeniusPlug. (Continued on next page.)

A

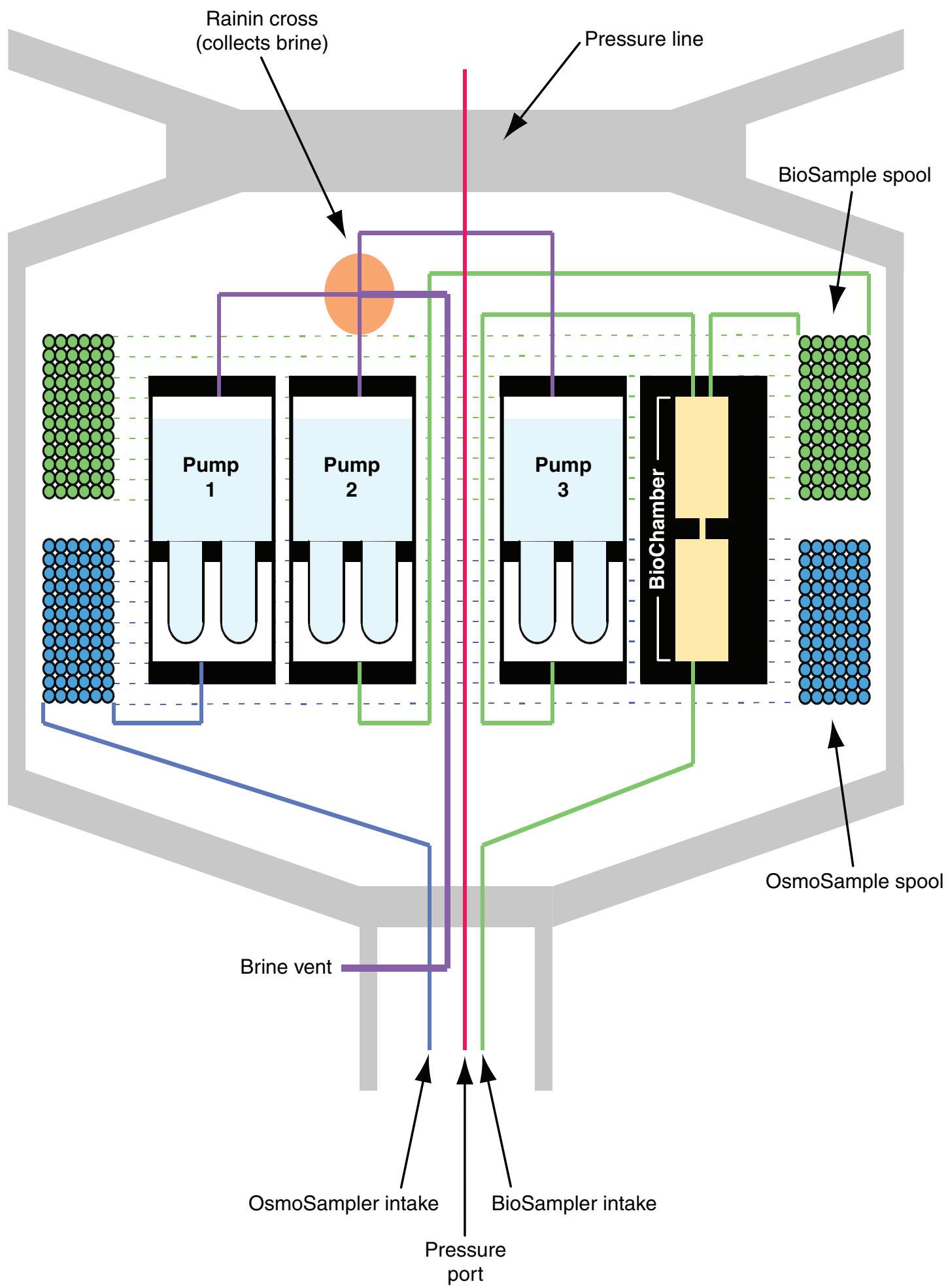


Figure F15 (continued). B. Photograph of the components hosted in the extension unit. FLOCS = flowthrough osmo colonization system.

B

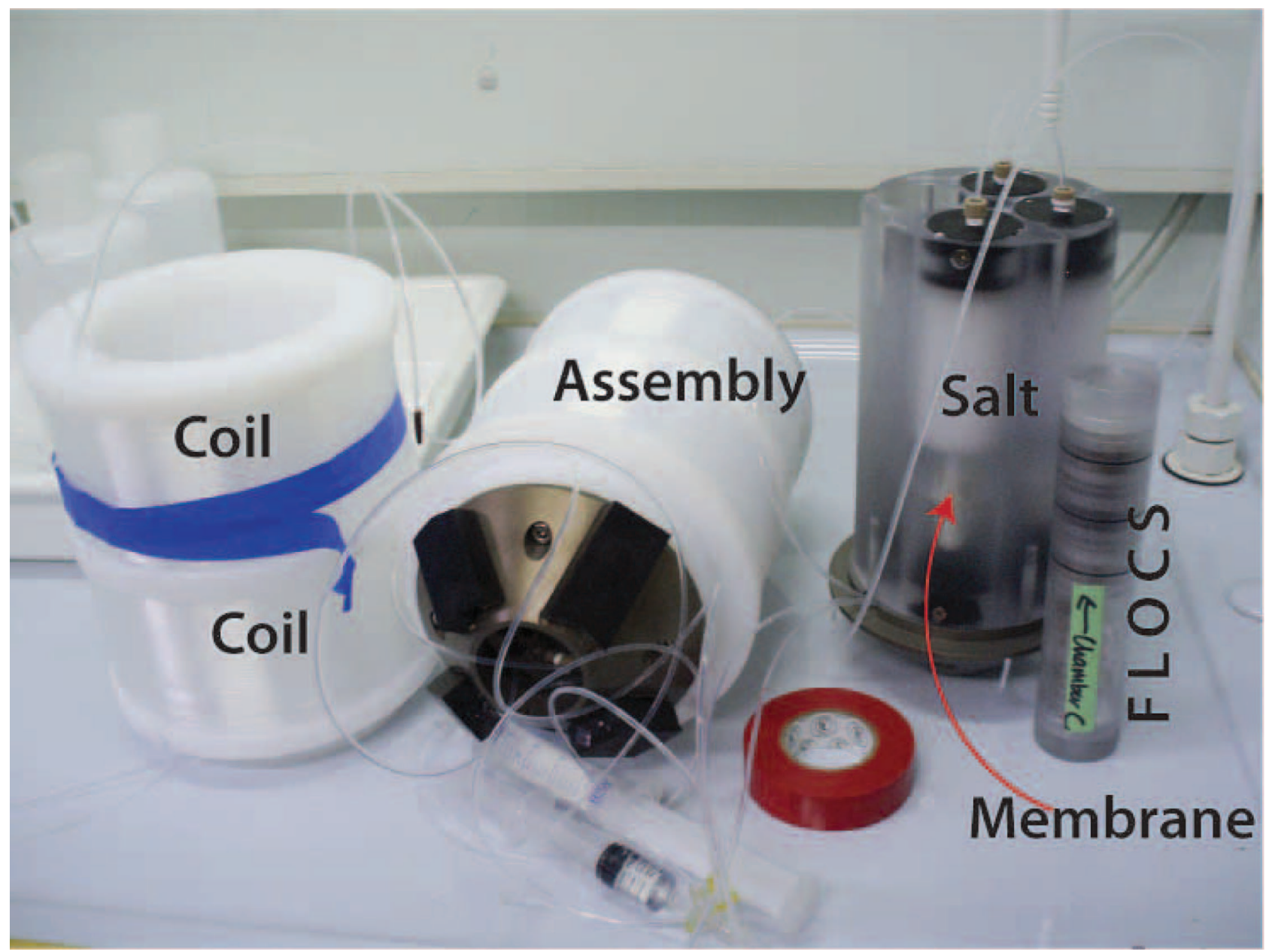


Figure F16. Hole C0002G completion assembly.

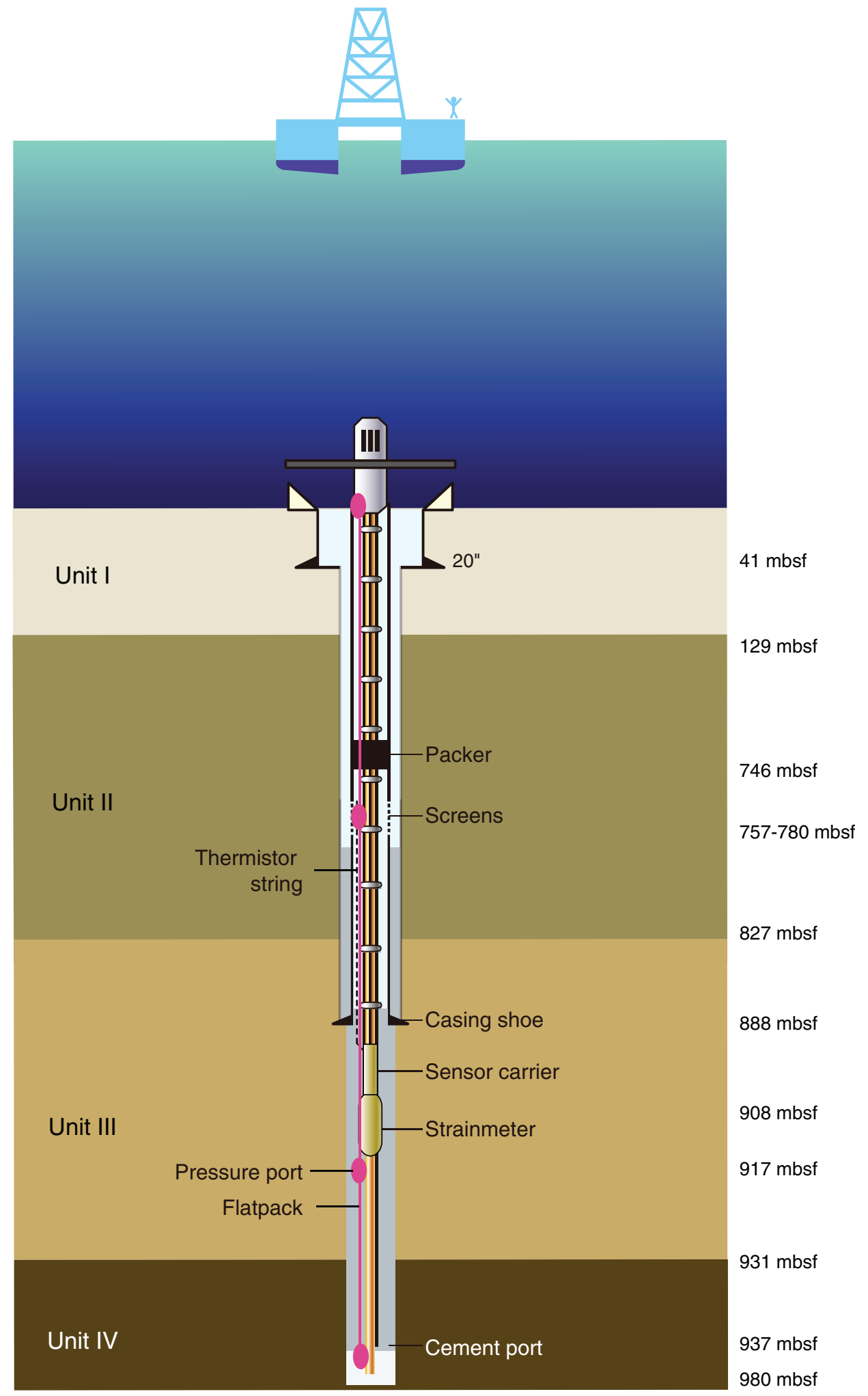


Figure F17. Miniscreen arrangement above bullnose on $3 \frac{1}{2} 2$ inch tubing.
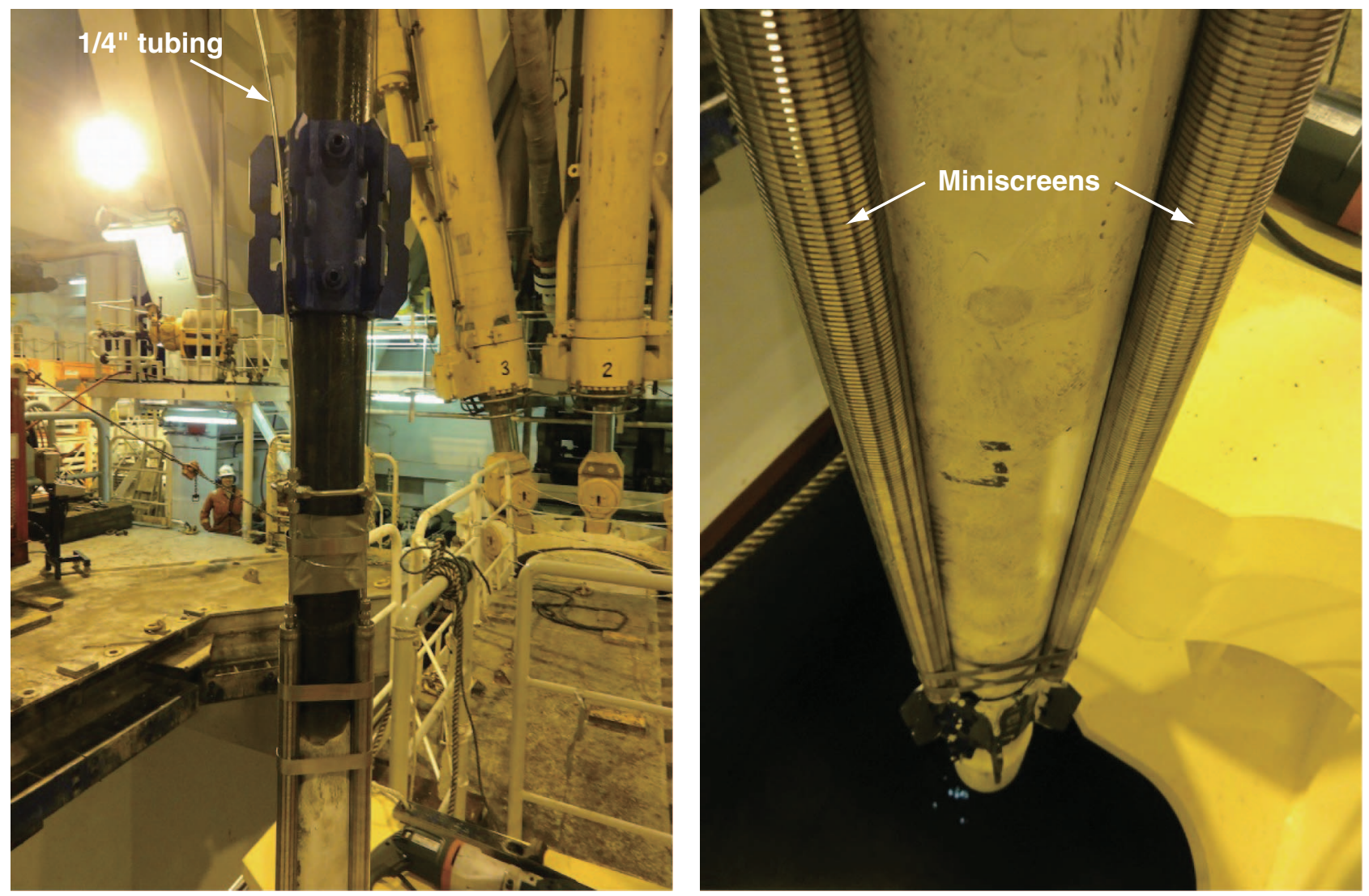
Figure F18. Swellable packer in moonpool area.

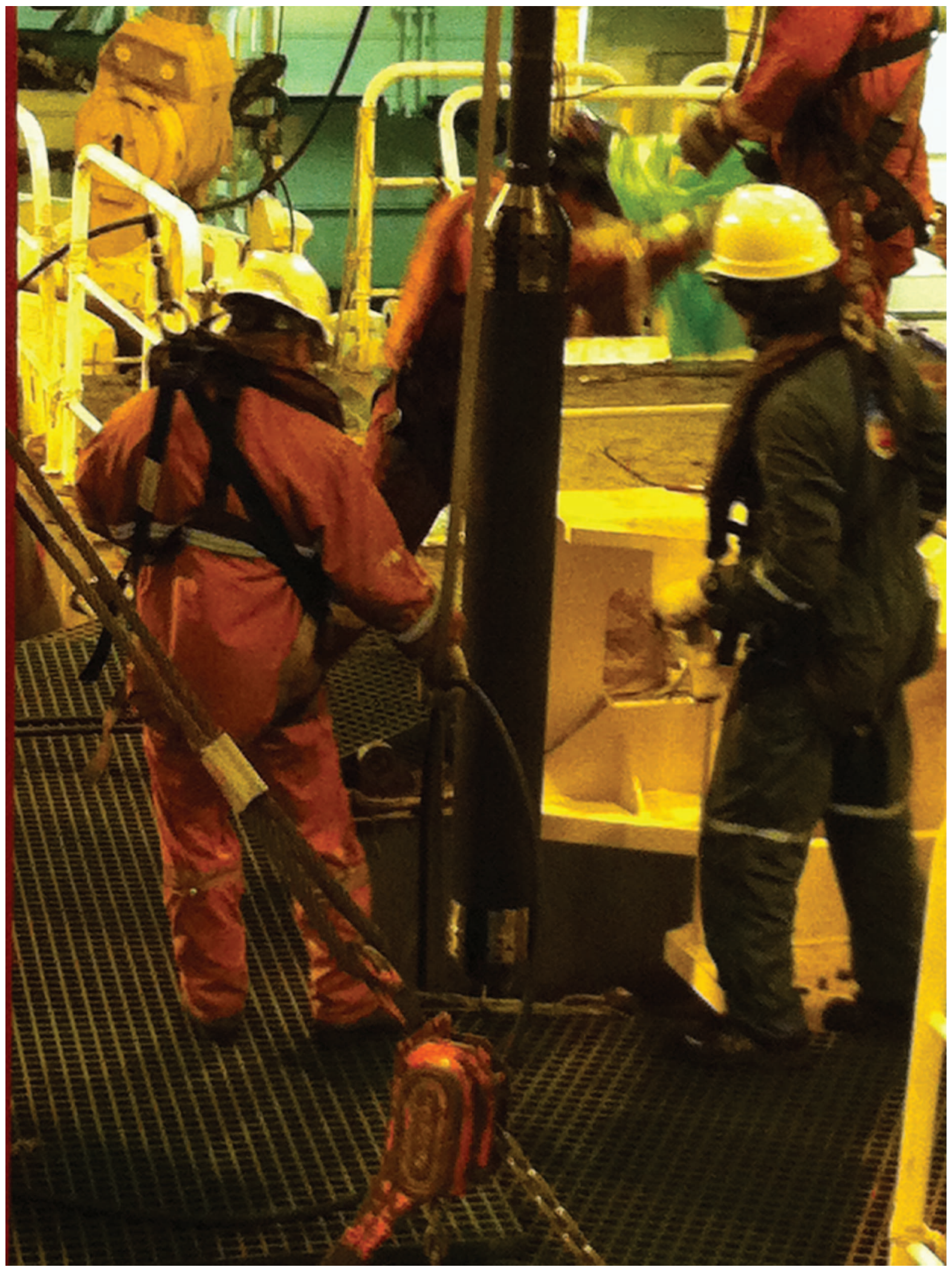


Figure F19. Pressure unit carrier on CORK head.

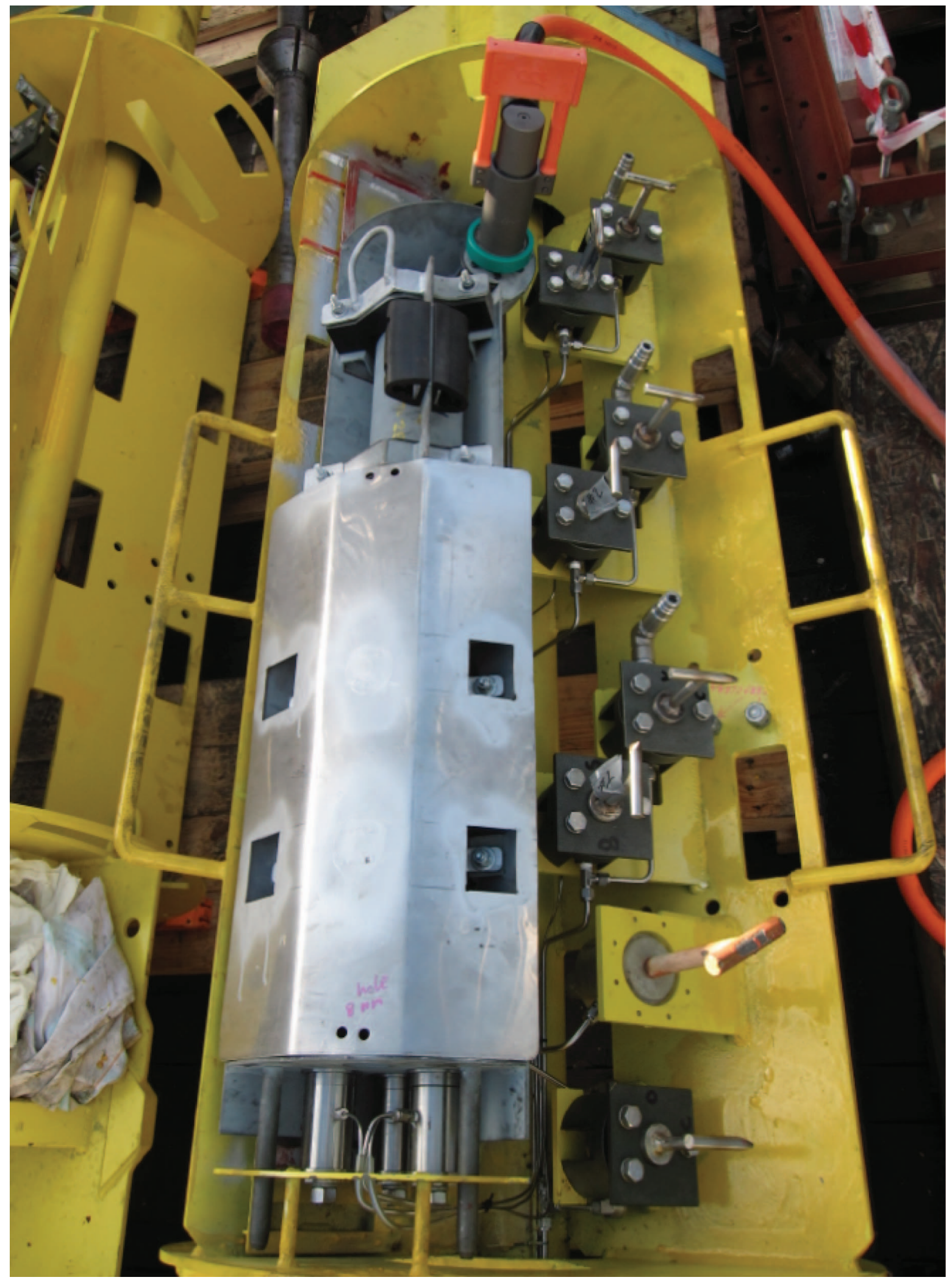


Figure F20. Strainmeter on completion string being run into the moonpool.

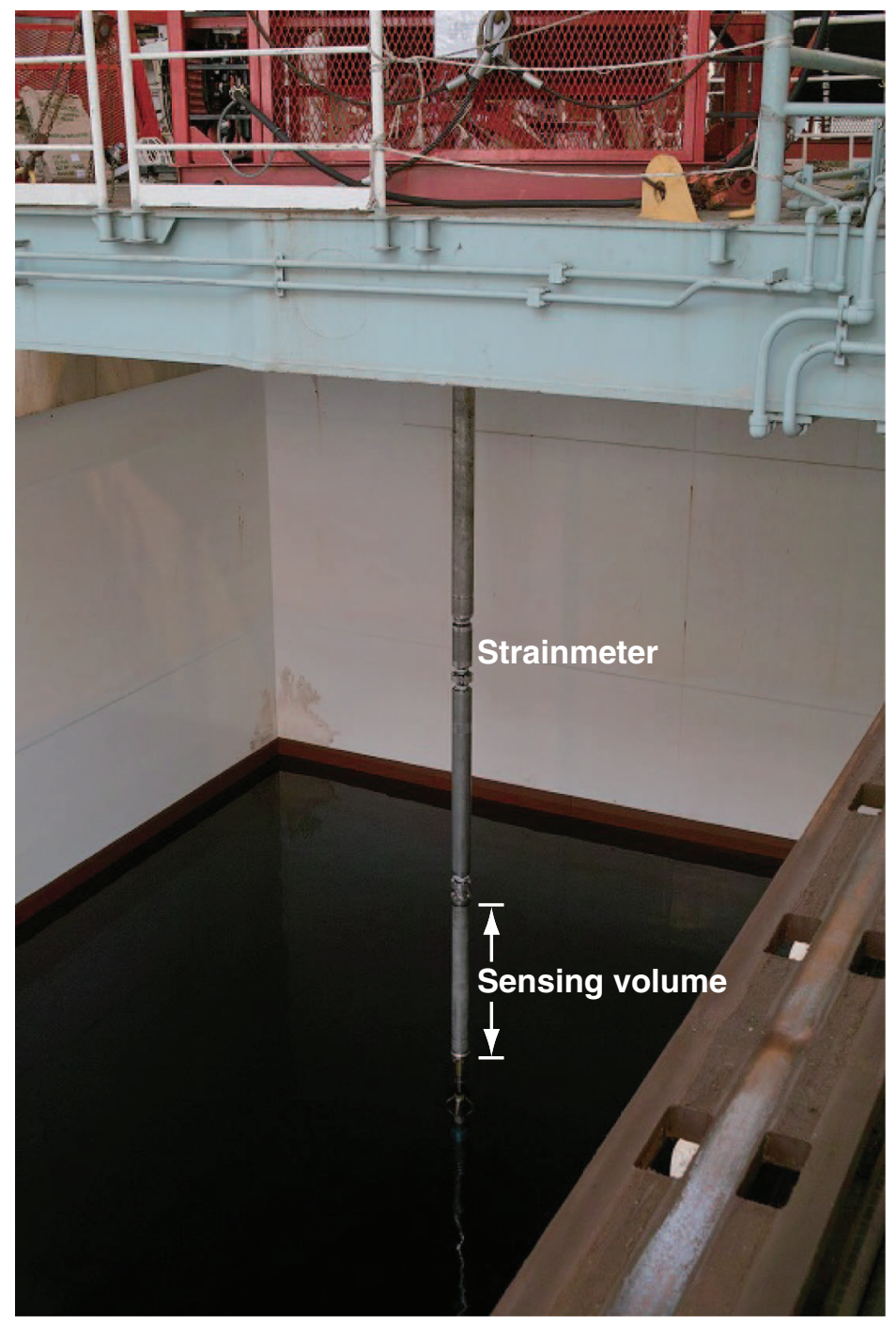


Figure F21. Instrument carrier, showing (attached from the bottom up) Guralp broadband seismometer, LILY tiltmeter, stand-alone heat flow meter (SAHF) digitizer, and geophone and accelerometer module.

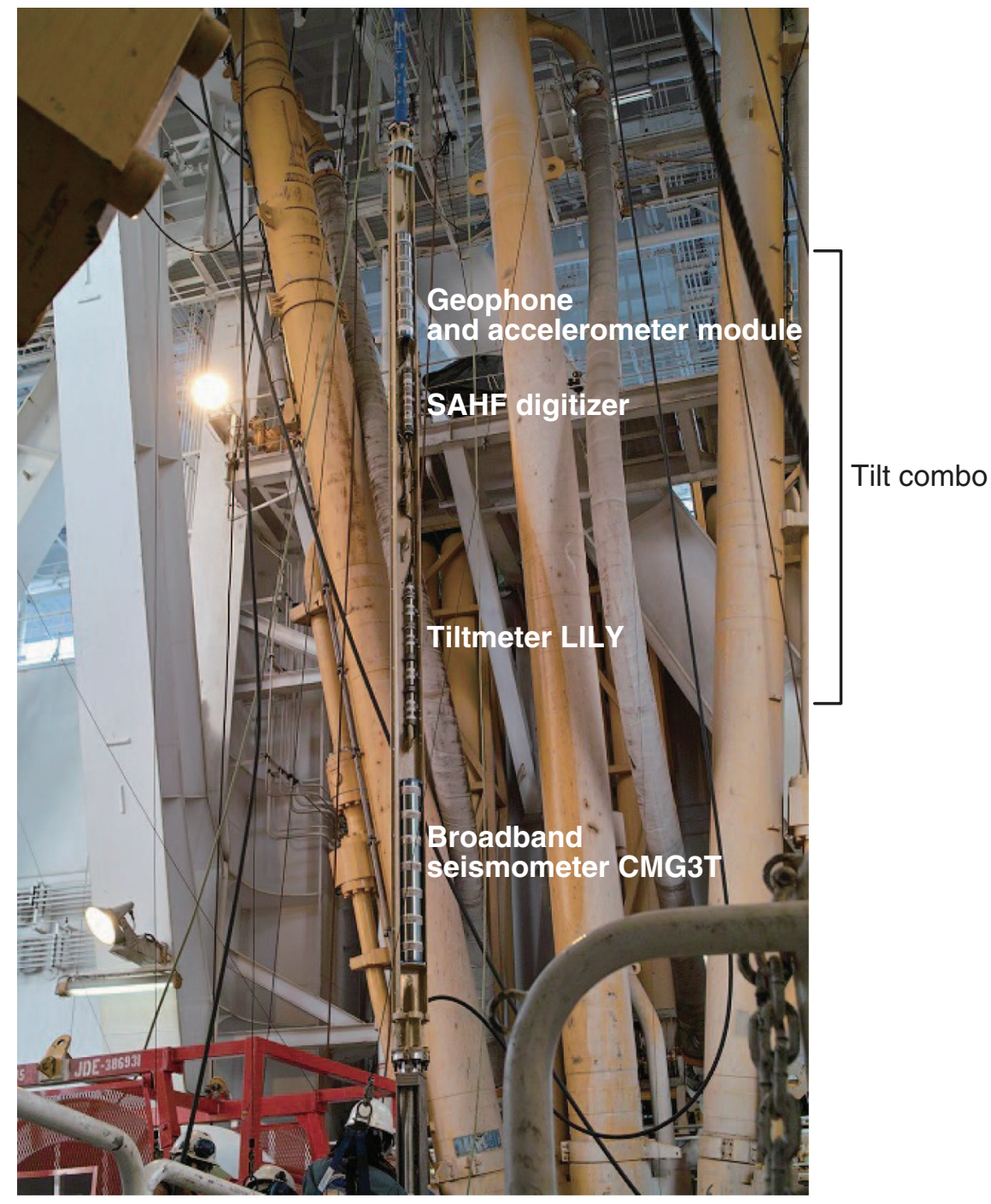


Figure F22. One of the thermometer nodes on the thermistor string. White cable ties keep it secured to the completion string.

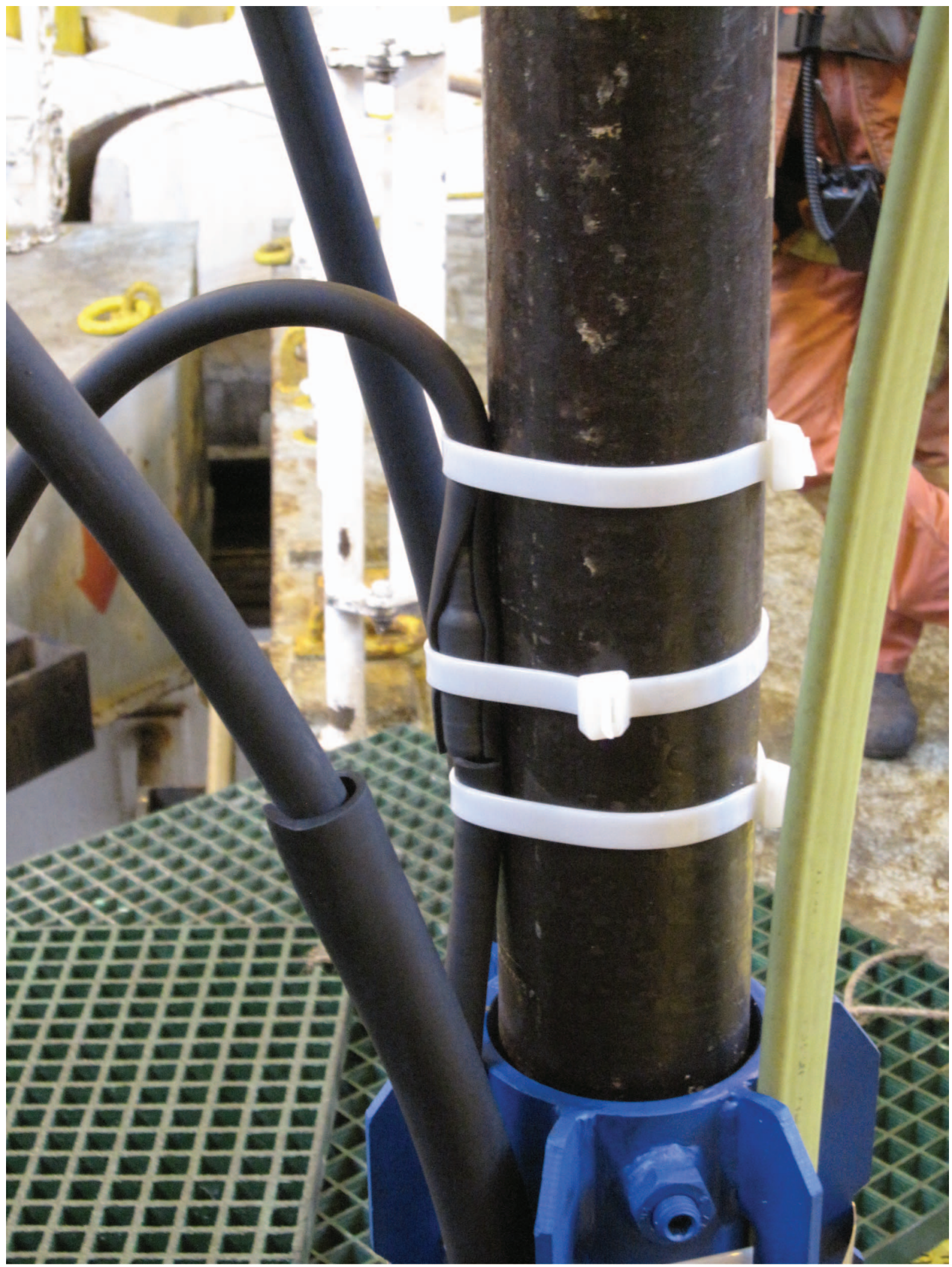


Figure F23. CORK head photographs. A. Pressure data logger bay. B. Ocean Design, Inc. (ODI) underwater mateable connectors for borehole instruments. ROV = remotely operated vehicle.
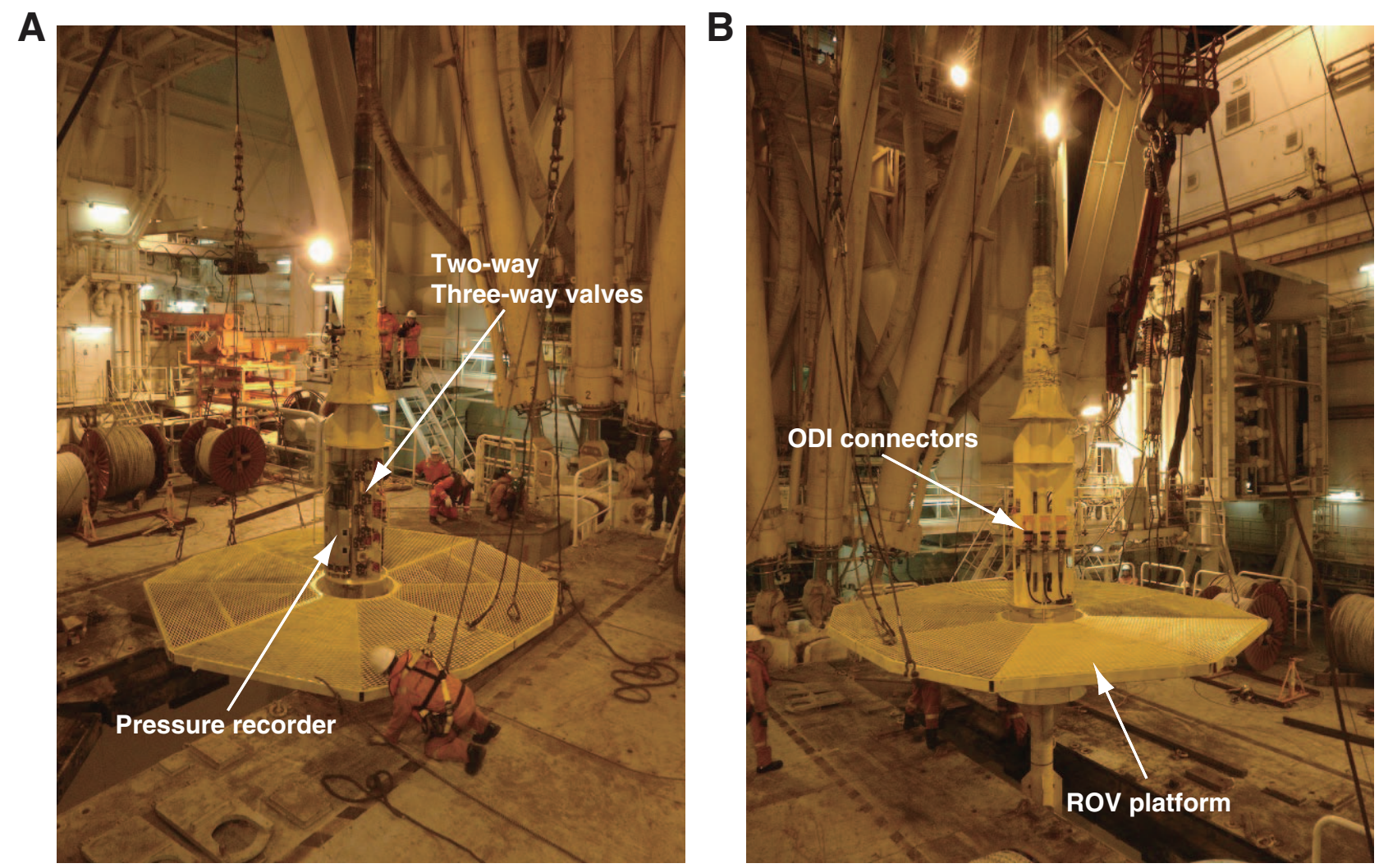
Figure F24. Schematic drawing of the CORK head with ROV platform viewed from above.

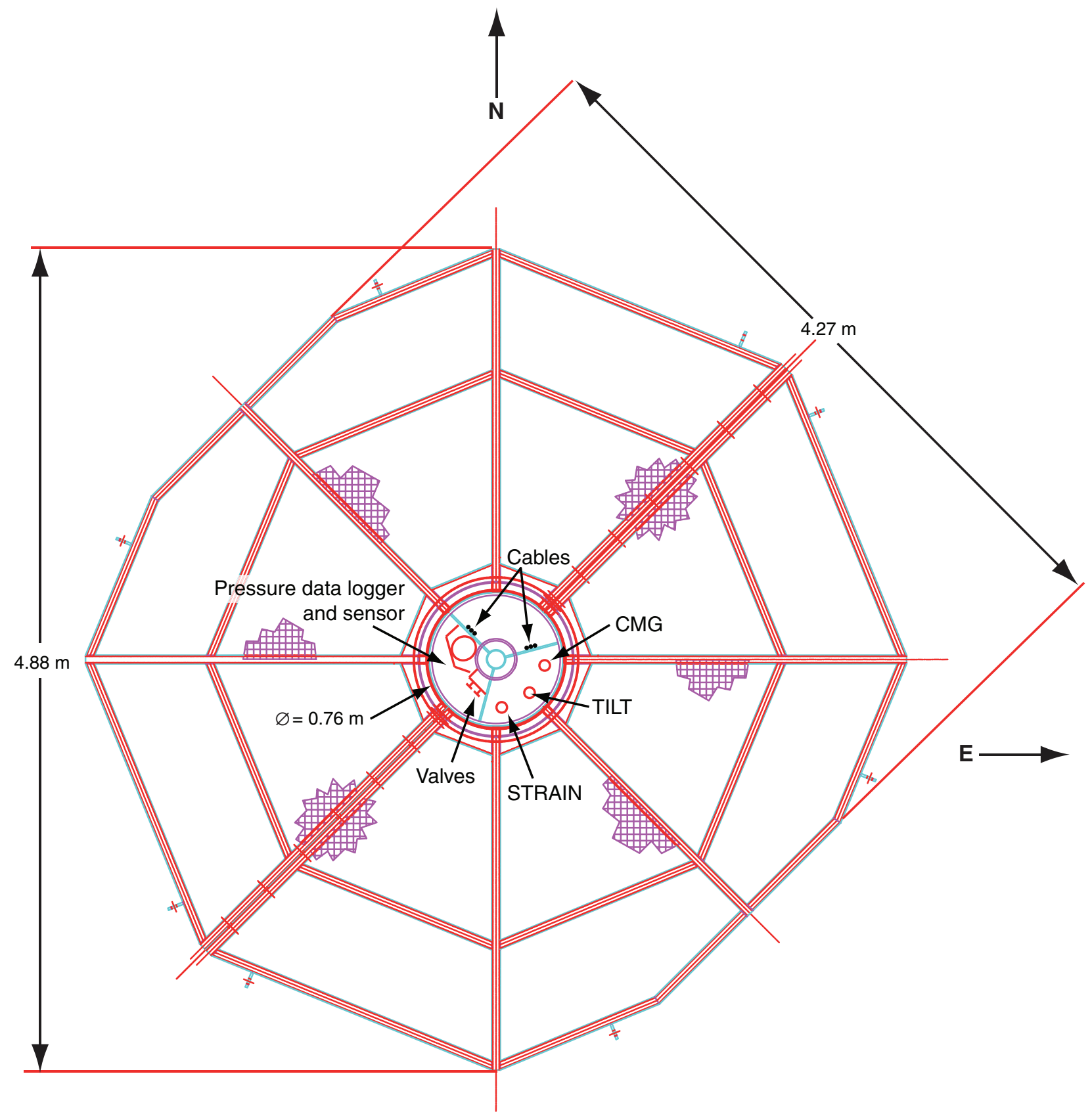


Figure F25. Remotely operated vehicle (ROV) video snapshots of the CORK head, showing (A) CORK head and ROV platform as they are lowered through the water column and (B) downloading pressure data from the sensor carrier in the pressure bay of the CORK head after cementing.

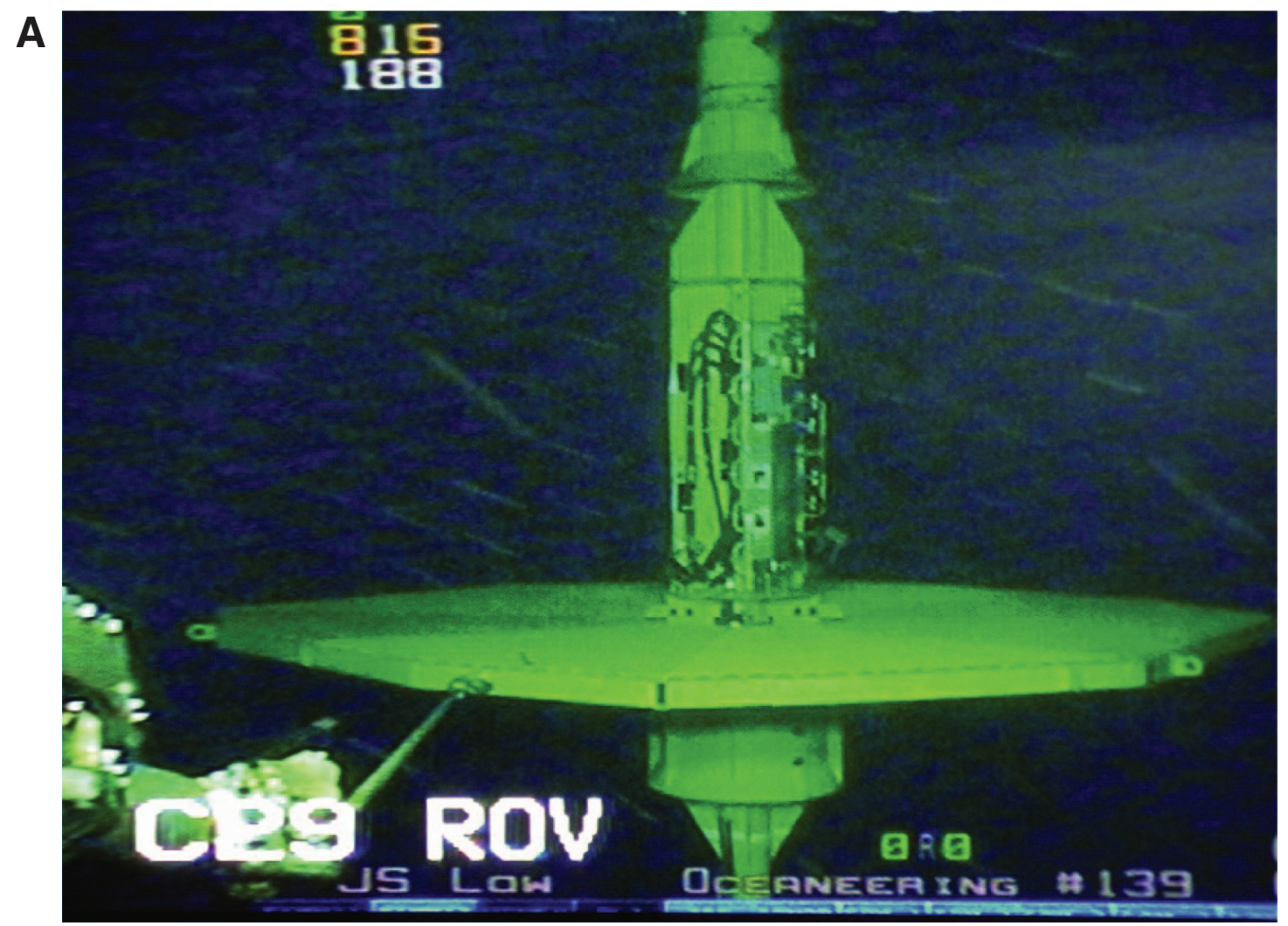

B

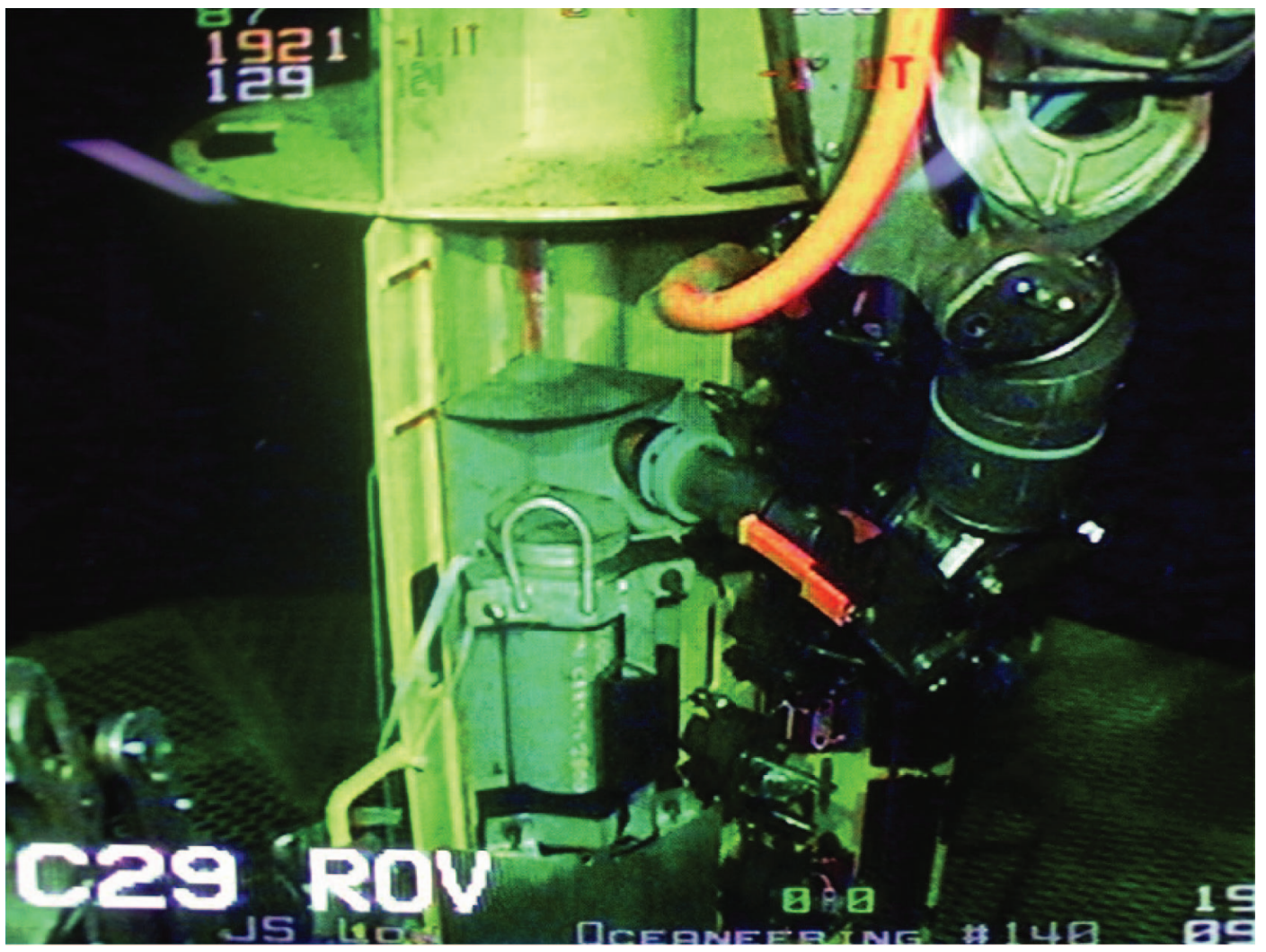


Figure F26. Initial pressure data from Site C0002 CORK LTBMS during cementing and after starting observation. UTC = Universal Time Coordinated.

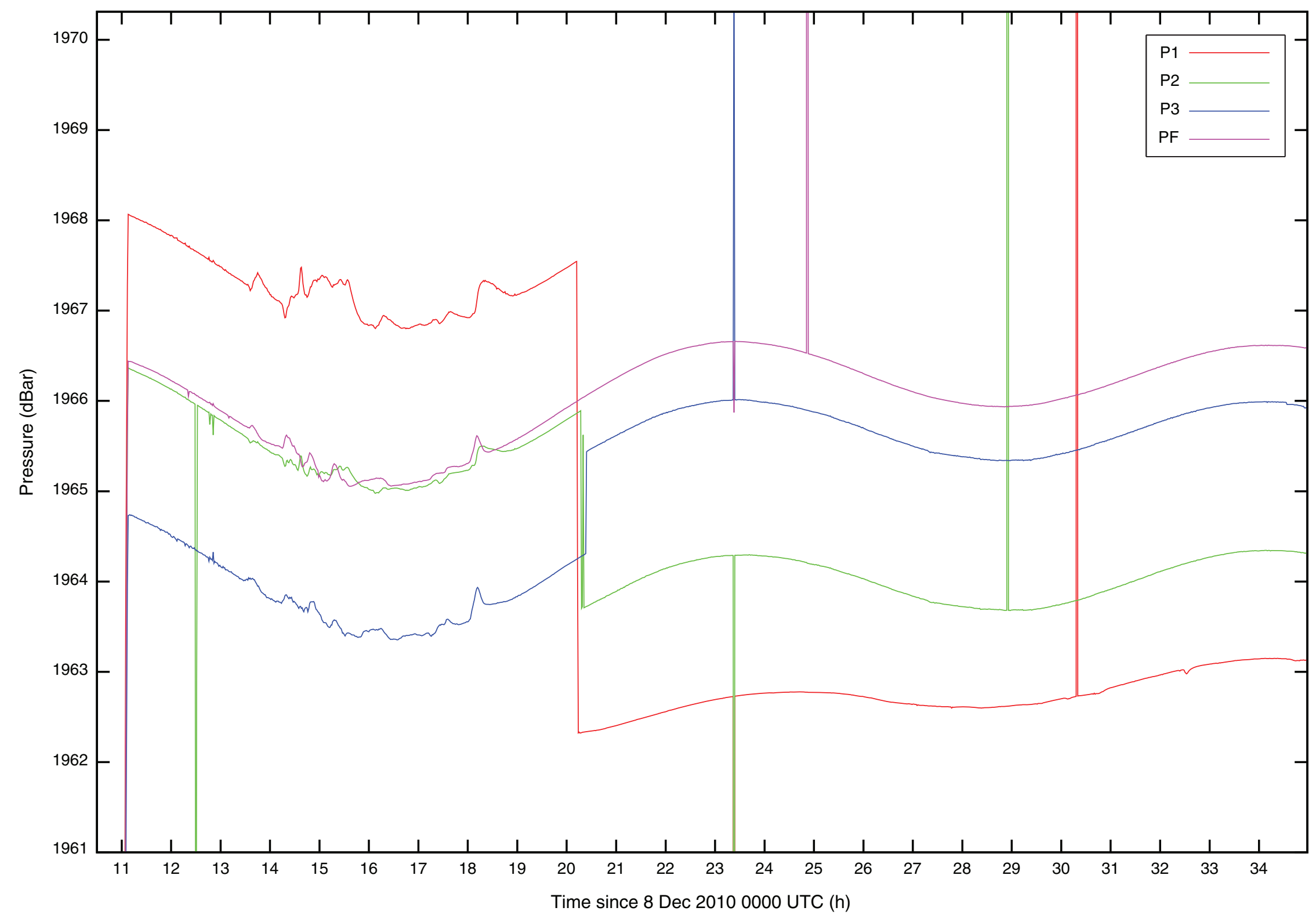


Table T1. Hole operation summary, Expedition 332.

\begin{tabular}{|c|c|c|c|c|c|c|c|c|}
\hline Hole & Latitude & Longitude & $\begin{array}{l}\text { Water depth } \\
\text { MSL (m) }\end{array}$ & Operations & $\begin{array}{c}\text { Drilled } \\
\text { interval } \\
(\mathrm{m})\end{array}$ & $\begin{array}{l}\text { Cased } \\
\text { interval } \\
(\mathrm{m})\end{array}$ & $\begin{array}{l}\text { Total } \\
\text { penetration } \\
(\mathrm{m})\end{array}$ & $\begin{array}{l}\text { Time on } \\
\text { site (days) }\end{array}$ \\
\hline $\mathrm{C} 0002 \mathrm{G}$ & $33^{\circ} 18.0130^{\prime} \mathrm{N}$ & $136^{\circ} 38.1500^{\prime} \mathrm{E}$ & 1936 & Set casing, MWD, LWD, LTBMS deployment & 980.0 & 887.0 & 980.0 & 27 \\
\hline \multirow[t]{2}{*}{ C0010A } & $33^{\circ} 12.5981^{\prime} \mathrm{N}$ & $136^{\circ} 41.1924^{\prime} \mathrm{E}$ & 2552 & SmartPlug recovery, GeniusPlug deployment & 0.0 & 0.0 & 0.0 & 12 \\
\hline & & & & Expedition 332 totals: & 980.0 & 887.0 & 980.0 & 39 \\
\hline
\end{tabular}

MWD = measurement while drilling, LWD = logging while drilling. LTBMS = long-term borehole monitoring system. 